\title{
Genetics of SCID
}

\author{
Fausto Cossu
}

\begin{abstract}
Human SCID (Severe Combined Immunodeficiency) is a prenatal disorder of T lymphocyte development, that depends on the expression of numerous genes. The knowledge of the genetic basis of SCID is essential for diagnosis (e.g., clinical phenotype, lymphocyte profile) and treatment (e.g., use and type of pre-hematopoietic stem cell transplant conditioning).

Over the last years novel genetic defects causing SCID have been discovered, and the molecular and immunological mechanisms of SCID have been better characterized. Distinct forms of SCID show both common and peculiar (e.g., absence or presence of nonimmunological features) aspects, and they are currently classified into six groups according to prevalent pathophysiological mechanisms: impaired cytokine-mediated signaling; pre-T cell receptor defects; increased lymphocyte apoptosis; defects in thymus embryogenesis; impaired calcium flux; other mechanisms.

This review is the updated, extended and largely modified translation of the article "Cossu F: Le basi genetiche delle SCID", originally published in Italian language in the journal "Prospettive in Pediatria" 2009, 156:228-238.
\end{abstract}

\section{Introduction}

The initial clinical manifestations of SCID (Severe Combined Immunodeficiency), a heterogeneous group of genetic defects with an overall incidence of about 1 in 40,000 to 75,000 newborns [1-3], are most frequently observed in the first few months of life and the median age at diagnosis is 4-7 months. However, human SCID is a prenatal disorder of $T$ lymphocyte development, already present at birth even if clinically silent in most affected newborns.

On January 1, 2008, Wisconsin (USA) became the first state in the world to screen all newborns for SCID through a method based on measurement of $\mathrm{T}$ cell receptor excision circles (TRECs) by polymerase chain reaction (PCR), using DNA extracted from newborn dried blood spots (Guthrie cards); TRECs are byproducts generated during normal $\mathrm{T}$ cell maturation (Figure 1) and are consistently absent or present in very low numbers in newborns with SCID [4]. Recently an infant with SCID has been identified by newborn screening in Massachusetts [5], and the U.S. Department of Health and Human Services recommended the addition of SCID to the uniform screening panel for all newborns [6].

\section{Correspondence: fcossu@mcweb.unica.it}

Pediatric HSCT Unit, $2 \wedge$ Pediatric Clinic of University, Ospedale Microcitemico, Via Jenner s/n, 09121 Cagliari, Sardinia, Italy
Wisconsin SCID screening poster (Figure 2) describes the fundamental features of SCID: children with SCID do not produce $\mathrm{T}$ lymphocytes (or, however, functional $\mathrm{T}$ lymphocytes), acquire multiple, persistent and severe viral, bacterial and fungal infections shortly after birth, fail to thrive, and rarely reach their first birthday; SCID is a pediatric emergency [7]: with prompt diagnosis and treatment and before acquiring an infection, including infections from "live" vaccines (e.g., Bacille CalmetteGuérin, and recently rotavirus) [8,9], essentially every baby with SCID could be cured by hematopoietic stem cell transplantation (HSCT) or gene therapy (GT).

It is very useful to remember other general aspects of SCID:
- Most newborns with SCID appear normal and healthy at birth; slight cutaneous signs similar to GvHD (Graft versus Host Disease) from engraftment of transplacentally derived maternal $\mathrm{T}$ lymphocytes are sometimes present. Instead, low birth length and weight, microcephaly, dysmorphic facies, metaphy- seal chondrodysplasia or other skeletal abnormalities, alopecia, congenital heart disease, etc. are nonimmu- nological manifestations of the less frequent forms of SCID in which cell types and organs other than lymphocytes and lymphoid organs are also affected by their genetic mutations (Table 1 ). 




Figure 1 T cell Receptor Excision Circles (TRECs). TRECs are episomal DNA circles produced in thymocytes by excisional rearrangements of T cell receptor (TCR) genes; they are stable, not duplicated during mitosis, diluted out with each cell division, and therefore higher in thymocytes, recent thymic emigrants (RTEs) and naïve T cells. Quantitative polymerase chain reaction (PCR) of coding-joint (cj) $\delta$ Rec $\psi J \alpha$ TREC, produced at TCR $\alpha / \delta$ locus within chromosome 14 (14q11) by $>70 \%$ of developing human $\alpha: \beta$ T cells, counts in the peripheral blood naïve $\alpha: \beta$ T lymphocytes recently dismetted by thymus: in newborn, values $<25 \mathrm{TRECS} / \mu \mathrm{L}$ indicate SCID.

- As noted above, even if most newborns with SCID appear normal at birth, SCID is always a prenatal disorder of the development of $T$ lymphocytes and it is already present at birth. In fact, the newborn screening through TRECs does neither measure enzyme activity nor search for mutations: it only counts normal naïve $\mathrm{T}$ lymphocytes, already absent or markedly reduced. Note that unlike mice (in



Figure 2 Wisconsin Newborn SCID screening poster. Reproduced with kind permission of the WI State Laboratory of Hygiene, http://www.slh.wisc.edu/posters/Baker102808.pdf. 
Table 1 Classification of SCID

\begin{tabular}{|c|c|c|c|c|c|c|}
\hline Prevalent mechanisms/Disease & T/B/NK & Gene & Locus & Heredity & Protein $^{\S \S}$ & Nonimmunological manifestations \\
\hline \multicolumn{7}{|c|}{ Impaired cytokine-mediated signaling } \\
\hline Common $\gamma$ chain defect & $\mathrm{TB}^{+} \mathrm{NK}^{-}$ & IL2RG & Xq13.1 & $X L$ & Common $\gamma$ chain & \\
\hline JAK3 defect & $\mathrm{TB}^{+} \mathrm{NK}^{-}$ & JAK3 & 19p13.1 & $A R$ & Janus kinase 3 & \\
\hline IL-7R $\alpha$ chain defect & $\mathrm{TB}^{+} \mathrm{NK}^{+}$ & IL7RA & $5 p 13$ & $A R$ & $\begin{array}{l}\text { IL-7 and TSLP } \\
\text { receptor } \alpha \text { chain }\end{array}$ & \\
\hline \multicolumn{7}{|l|}{ Defects of the pre-T cell receptor } \\
\hline \multicolumn{7}{|l|}{ Defects in $V(D) J$ recombination } \\
\hline RAG1 defect & $\mathrm{TBNK}^{+}$ & RAG1 & $11 \mathrm{p} 13$ & AR & RAG1 & \\
\hline RAG2 defect & $\mathrm{TBNK}^{+}$ & RAG2 & $11 \mathrm{p} 13$ & AR & RAG2 & \\
\hline Artemis defect & $\mathrm{TBNK}^{+}$ & DCLREIC & 10p13 & $A R$ & Artemis & radiosensitivity \\
\hline DNA-PKcs defect & $\mathrm{TBNK}^{+}$ & PRKDC & $8 q 11.21$ & $A R$ & DNA-PKCS & radiosensitivity \\
\hline DNA ligasi IV defect & $\mathrm{TB}^{-} \mathrm{NK}^{+}$ & LIG4 & $13 q 33.3$ & $A R$ & DNA ligasi IV & $\begin{array}{l}\text { radiosensitivity, dysmorphic facies, } \\
\text { microcephaly, growth } \\
\text { retardation, psychomotor delay }\end{array}$ \\
\hline Cernunnos/XLF defect & $\mathrm{TB}^{-} \mathrm{NK}^{+}$ & NHEJ1 & $2 q 35$ & $A R$ & Cernunnos/XLF & $\begin{array}{l}\text { radiosensitivity, dysmorphic facies, } \\
\text { microcephaly, growth } \\
\text { retardation, psychomotor delay }\end{array}$ \\
\hline
\end{tabular}

Impaired signaling through the pre-T

cell receptor

\begin{tabular}{|c|c|c|c|c|c|c|}
\hline CD38 defect & $\mathrm{TB}^{+} \mathrm{NK}^{+}$ & CD3D & $11 q 23$ & $A R$ & $\mathrm{CD} 3 \delta$ & \\
\hline CD3e defect & $\mathrm{TB}^{+} \mathrm{NK}^{+}$ & CD3E & $11 q 23$ & $A R$ & $\mathrm{CD} 3 \varepsilon$ & \\
\hline 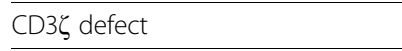 & $\mathrm{TB}^{+} \mathrm{NK}^{+}$ & CD3Z & $1 \mathrm{q} 24.2$ & $A R$ & CD3ל & \\
\hline CD3 $\gamma$ defect & $\mathrm{TB}^{+} \mathrm{NK}^{+}$ & CD3G & $11 \mathrm{q} 23$ & $A R$ & $\mathrm{CD} 3 \gamma$ & \\
\hline$\overline{C D} 45$ & $\begin{array}{l}\mathrm{TB}^{+} \mathrm{NK}^{-1} \\
+\end{array}$ & PTPRC & $1 \mathrm{q} 31.3$ & $A R$ & CD45 (LCA) & \\
\hline \multirow[t]{2}{*}{ ZAP-70 defect } & $\mathrm{T}^{+} \mathrm{B}^{+} \mathrm{NK}^{+}$ & ZAP70 & $2 q 11.2$ & $A R$ & ZAP-70 & \\
\hline & $\begin{array}{l}\mathrm{CD}^{+} \\
\mathrm{CD}^{-}\end{array}$ & & & & & \\
\hline p56lck defect & $\mathrm{TB}^{+} \mathrm{NK}^{+}$ & LCK & $1 \mathrm{p} 35.1$ & $A R$ & p56lck & \\
\hline \multicolumn{7}{|l|}{ Increased lymphocyte apoptosis } \\
\hline Reticular dysgenesis & $\mathrm{TB}^{\mathrm{N} N K^{-}}$ & $A K 2$ & $1 p 34$ & $A R$ & $\begin{array}{l}\text { Adenylate kinase } \\
2\end{array}$ & aleukocytosis, sensorineural deafness \\
\hline ADA-SCID & $\mathrm{TB}^{\top} \mathrm{NK}^{-}$ & $A D A$ & $20 q 13.11$ & $A R$ & $\begin{array}{l}\text { Adenosine } \\
\text { deaminase }\end{array}$ & $\begin{array}{l}\text { costochondral and skeletal alterations, } \\
\text { neonatal hepatitis, sensorineural deafness, } \\
\text { neurological problems }\end{array}$ \\
\hline PNP-SCID & TBNKK' $^{-}$ & PNP & $14 q 11.2$ & $A R$ & $\begin{array}{l}\text { Purine } \\
\text { nucleoside } \\
\text { phosphorylase }\end{array}$ & neurological problems \\
\hline \multicolumn{7}{|l|}{ Defects in thymus embryogenesis } \\
\hline Nude/SCID Syndrome & $\mathrm{TB}^{+} \mathrm{NK}^{+}$ & WHN & $17 q 11.2$ & $A R$ & FOXN1 & alopecia; embryonic neural tube defects \\
\hline \multicolumn{7}{|l|}{ Complete DiGeorge Anomaly } \\
\hline DiGeorge Syndrome (del22q11.2) & $\mathrm{TB}^{+} \mathrm{NK}^{+}$ & $\begin{array}{l}>35 \\
\text { genes }\end{array}$ & $22 q 11.2$ & $A D$ & TBX1, and others & $\begin{array}{l}\text { dysmorphic facies, congenital heart disease } \\
\text { and other } \\
\text { malformations, neonatal hypocalcemia by } \\
\text { absence of } \\
\text { parathyroid glands }\end{array}$ \\
\hline CHARGE & $\mathrm{TB}^{+} \mathrm{NK}^{+}$ & CHD7 & $8 q 12.1$ & $A D$ & CHD-7 & $\begin{array}{l}\text { CHARGE association (coloboma, heart } \\
\text { defects, atresia } \\
\text { choanae, retardated growth and } \\
\text { development, genital } \\
\text { hypoplasia, ear anomalies/deafness) }\end{array}$ \\
\hline
\end{tabular}


Table 1 Classification of SCID (Continued)

\begin{tabular}{|c|c|c|c|c|c|c|}
\hline Diabetic mother embryopathy & $\mathrm{TB}^{+} \mathrm{NK}^{+}$ & & & & & $\begin{array}{l}\text { congenital heart disease, gut and kidney } \\
\text { malformations, } \\
\text { neural tube defects, sacral agenesis, } \\
\text { holoprosencephaly, } \\
\text { neonatal hypoglycemia }\end{array}$ \\
\hline \multicolumn{7}{|l|}{ Impaired calcium flux } \\
\hline ORAl1 defect & $\mathrm{T}^{+} \mathrm{B}^{+} \mathrm{NK}^{+}$ & ORAl1 & $12 q 24$ & $A R$ & ORAI1 & myopathy, ectodermal dysplasia \\
\hline STIM1 defect & $\mathrm{T}^{+} \mathrm{B}^{+} \mathrm{NK}^{+}$ & STIM1 & $11 p 15.5$ & $A R$ & STIM1 & myopathy, ectodermal dysplasia \\
\hline \multicolumn{7}{|l|}{ Other mechanisms } \\
\hline Coronin-1A defect & $\mathrm{TB}^{+} \mathrm{NK}^{+}$ & CORO1A & $16 p 11.2$ & $A R$ & Coronin-1A & \\
\hline \multirow[t]{4}{*}{ MHC Class II defect } & $\mathrm{T}^{+} \mathrm{B}^{+} \mathrm{NK}^{+}$ & CIITA & $16 p 13.13$ & $A R$ & CIITA & \\
\hline & $\begin{array}{l}\mathrm{CD}^{-} \\
\mathrm{CD}^{+}\end{array}$ & RFXANK & $19 p 13.11$ & $A R$ & RFXANK & \\
\hline & & RFX5 & $1 \mathrm{q} 21.2$ & $A R$ & RFX5 & \\
\hline & & RFXAP & $13 q 13.3$ & $A R$ & RFXAP & \\
\hline $\mathrm{CHH}$ (Cartilage hair hypoplasia) & $\mathrm{TB}^{+} \mathrm{NK}^{+}$ & $R M R P$ & 9p13.3 & $A R$ & $\begin{array}{l}\S \S \text { RNA of } \\
\text { RNase MRP } \\
\text { complex }\end{array}$ & $\begin{array}{l}\text { short-limbed dwarfism, light-colored } \\
\text { hypoplastic hair }\end{array}$ \\
\hline \multirow[t]{4}{*}{ Hoyeraal-Hreidarsson Syndrome (HHS) } & $\mathrm{T}^{+} \mathrm{B}^{-} \mathrm{NK}^{-}$ & DKC1 & $\mathrm{Xq} 28$ & $X L$ & Dyskerin & $\begin{array}{l}\text { cerebellar hypoplasia, microcephaly, growth } \\
\text { retardation, } \\
\text { bone marrow failure, hypoplastic hair }\end{array}$ \\
\hline & & TERT & $5 p 15.33$ & $A R$ & TERT & \\
\hline & & TINF2 & $14 q 12$ & $A D$ & TIN2 & \\
\hline & & $D C L R E 1 B$ & $1 \mathrm{p} 13.2$ & $A D$ & Apollo & \\
\hline Hereditary folate malabsorption (HFM) & $\mathrm{T}^{+} \mathrm{B}^{+} \mathrm{NK}^{+}$ & SLC46A1 & $17 q 11.2$ & $A R$ & PCFT & $\begin{array}{l}\text { megaloblastic anemia, seizures, risk of } \\
\text { severe } \\
\text { neurodevelopmental defects }\end{array}$ \\
\hline
\end{tabular}

which, contrary to humans, neonatal thymectomy causes SCID) normal development of the human immune system starts very early and it is notably advanced before birth: in absence of SCID, in human embryos (since 9-10 weeks of age) there is intensive thymic $\mathrm{T}$ lymphopoiesis; and human in utero exposure to foreign antigens does activate immunological response and does not produce tolerance, apart that toward noninherited maternal alloantigens (tolerance mediated by specific regulators $\mathrm{T}$ lymphocytes $\mathrm{CD} 4{ }^{+} \mathrm{CD} 25^{\text {high }} \mathrm{FoxP}^{+} \mathrm{T}_{\text {Reg }}$, that represent $15-20 \%$ of $\mathrm{CD} 4^{+} \mathrm{T}$ lymphocytes in the peripheral lymphoid organs of the human fetus) [10]. Therefore, in utero HSCT had success (also if usually partial: graft of $\mathrm{T}$ cells but not $\mathrm{B}$ cells) in human SCID fetuses, but failed completely - 0\% successful (!!) with moreover $24 \%$ "procedure-related death" - in 17/17 fetuses with hemoglobinopathies (thalassemia, sickle cell disease) and normal immune system [11].

- The development and function of T lymphocytes are severely compromised in all forms of SCID ("congenital severe $\mathrm{T}$ cell immunodeficiencies"); however, T lymphocytes, B lymphocytes and NK (natural killer) lymphocytes (note that NK cells, unlike $T$ and $B$ lymphocytes, do not rearrange their germline DNA to produce genes encoding antigenspecific receptors) share progenitors for cell lineages, signaling pathways in development and function, and metabolic pathways. Therefore, also B lymphocytes and/or NK cells are usually severely compromised in SCID, and the distinct forms of SCID are characterized by different combinations of $T / B / N K$ counts: $\mathbf{T}^{-} \mathbf{B}^{-} \mathbf{N} \mathbf{K}^{-}, \mathbf{T}^{-} \mathbf{B}^{+} \mathbf{N} \mathbf{K}^{-}, \mathbf{T}^{-} \mathbf{B}^{-} \mathbf{N K}^{+}, \mathbf{T}^{-} \mathbf{B}^{+} \mathbf{N} \mathbf{K}^{+}$ ( means absence or severely reduced counts). Moreover, without normal $\mathrm{CD} 4^{+} \mathrm{T}$ helper lymphocytes $\left(\mathrm{T}_{\mathrm{H}} 1, \mathrm{~T}_{\mathrm{H}} 2, \mathrm{~T}_{\mathrm{Reg}}, \mathrm{T}_{\mathrm{FH}}, \mathrm{T}_{\mathrm{H}} 17, \mathrm{~T}_{\mathrm{H}} 22, \mathrm{~T}_{\mathrm{H}}\right.$ 9) [12,13], $\mathrm{B}$ lymphocytes (in SCID agammaglobulinemia is the rule, with rare exceptions), macrophages and also eventual residual $\mathrm{T}$ lymphocytes cannot work even if present and "normal".

- In most SCID the absence of T lymphocytes causes marked lymphopenia, with often an absolute lymphocyte count $(\mathrm{ALC})<500$ cells $/ \mu \mathrm{L}$. Note that in adults lymphopenia means ALC $<1,000 / \mu \mathrm{L}$, but the normal lower limits are $2,000 / \mu \mathrm{L}$ in newborns and $4,000 / \mu \mathrm{L}$ in infants by 6 to 9 months of age; therefore, in the first few months of life any ALC < $2,500 / \mu \mathrm{L}$ is potentially pathogenic and may indicate SCID [14].

- However, many infants with SCID have T cells, showing slightly reduced, normal $\left(\mathbf{T}^{+} \mathbf{S C I D}\right)$ or high 
( $\mathbf{T}^{++}$SCID) $\mathrm{T}$ cell counts: e.g., "functional" $\mathrm{T}^{+} \mathrm{B}^{+}$ $\mathrm{NK}^{+}$SCID in the defects of calcium channels [15], T ${ }^{+}\left(\mathrm{CD}^{+}{ }^{+} \mathrm{CD}^{-}\right) \mathrm{B}^{+} \mathrm{NK}^{+}$SCID in the defect of ZAP70 [16], $\mathrm{T}^{+} \mathrm{B}^{-} \mathrm{NK}^{-} \mathrm{SCID}$ in the Hoyeraal-Hreidarsson syndrome [17].

But, $\mathrm{T}^{+}$or $\mathrm{T}^{++}$SCID are most frequently due to abnormal and oligoclonal $T$ cells that modify counts from $\mathrm{T}^{-} \mathrm{B}^{-} \mathrm{NK}^{-}$to $\mathrm{T}^{+} \mathrm{B}^{-} \mathrm{NK}^{-}$, from $\mathrm{T}^{-} \mathrm{B}^{+} \mathrm{NK}^{-}$to $\mathrm{T}^{+} \mathrm{B}$ ${ }^{+} \mathrm{NK}^{-}$, from $\mathrm{T}^{-} \mathrm{B}^{-} \mathrm{NK}^{+}$to $\mathrm{T}^{+} \mathrm{B}^{-} \mathrm{NK}^{+}$, or from $\mathrm{T}^{-} \mathrm{B}^{+} \mathrm{NK}^{+}$ to $\mathrm{T}^{+} \mathrm{B}^{+} \mathrm{NK}^{+}$. Such abnormal $\mathrm{T}$ lymphocytes (oligoclonal V $\beta$ TCR families; very low naïve $\mathrm{CD} 4$ ${ }^{+} \mathrm{CD} 45 \mathrm{RA}^{+} \mathrm{T}$ cells; high memory $\mathrm{CD} 4{ }^{+} \mathrm{CD} 45 \mathrm{RO}^{+} \mathrm{T}$ cells; high activated $\mathrm{CD} \mathrm{DR}^{+} \mathrm{T}$ cells; very low/absent in vitro mitogen-induced lymphocyte proliferation; and, very low/absent TRECs, that is very important regard to newborn SCID screening) are present in two main conditions:

1) SCID with massive engraftment of transplacentally derived maternal $T$ lymphocytes: such maternal $\mathrm{T}$ lymphocytes are very useful for the diagnosis of SCID (HLA typing of infant's peripheral blood; maternal DNA in infant's peripheral blood), and may also cause various and unusual manifestations: skin and liver GvHD [18], autoimmune thrombocytopenia or pancytopenia (pre- or post-HSCT), rejection of HSCT from father or donors other than mother [19], monoclonal gammopathy because of clonal expansion of maternal or newborn $\mathrm{B}$ cells in absence of normal CD4 ${ }^{+} \mathrm{T}_{\text {Reg }}$ lymphocytes (Figure 3) [20], attenuated clinical SCID if fetus/mother HLA compatibility [21].

2) Omenn Syndrome: caused by hypomorphic mutations ("leaky SCID") not only of rag1-rag2 (recombination activating gene 1-2) [22] but also of almost all other genes whose null mutations cause instead typical SCID (Figure 4) [16,23-32]. Clinically, Omenn syndrome is not a "leaky" SCID and has a poor prognosis; it is an extremely serious $\mathrm{T}^{+}$or $\mathrm{T}^{++}$ SCID with pathogenic child's (not maternal) autologous oligoclonal hyper-autoreactive $\mathrm{CD}^{+} \mathrm{T}_{\mathrm{H}} 2$ lymphocytes, produced because of non-null mutations and then expanded by lack of central and peripheral immunological tolerance (respectively: thymic defect of thymocyte-dependent epithelial and dendritic cells and of AIRE, Autoimmune Regulator Element, expression; and defect of $\mathrm{CD} 4^{+} \mathrm{T}_{\text {Reg }}$ lymphocytes)

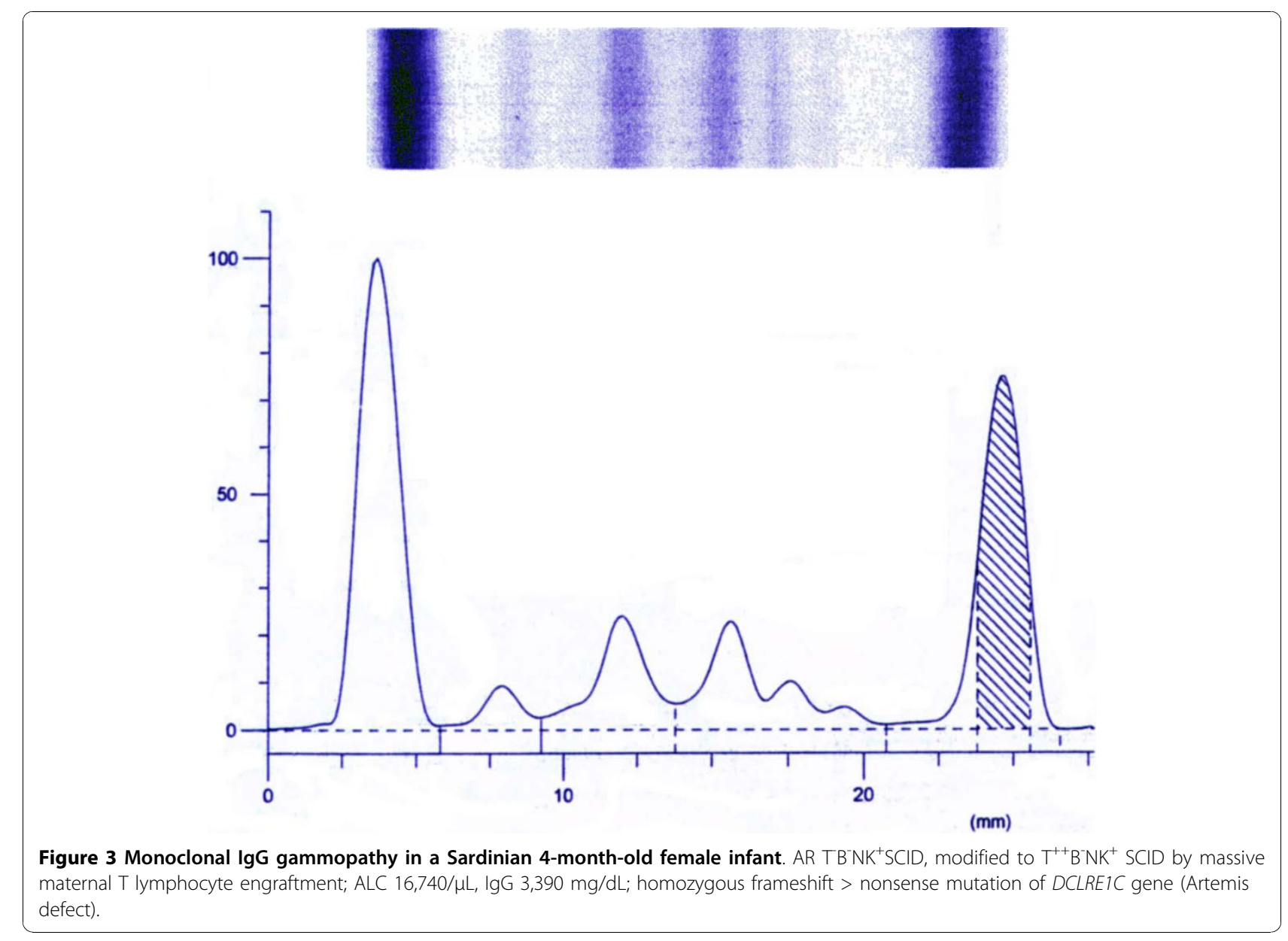




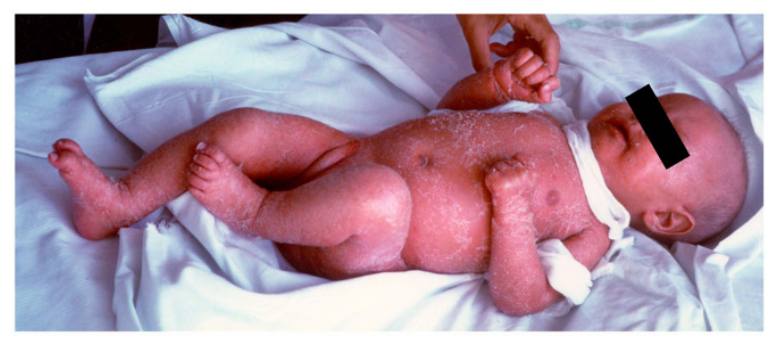

Figure 4 Omenn Syndrome in a Sardinian 5-month-old female infant (absence of RAG1-RAG2 mutations, unidentified gene defect). "Leaky" mutations of practically all SCID genes (whose null mutations cause instead typical SCID) produce Omenn syndrome, in fact described in infants with defects of RAG1-RAG2, DCLRE1CArtemis, ADA, DNA Ligasi IV, RMRP-CHH, common $\gamma c$, IL7R $\alpha$, WHNFOXN1, ZAP-70, and complete DiGeorge anomaly (DiGeorge Syndrome; (HARGE). In many infants with Omenn syndrome, that is clinically not leaky but very serious, genetic defect remains unidentified (several known, and probably also unknown, genes to be sequenced).

[23,33-35]. Besides the overwhelming and life-threatening infections typical of SCID, Omenn infants present with aggressive tissue inflammation, very severe erythroderma (absent at birth), protein loss through the skin and the gut, unmanageable diarrhea, generalized edema, metabolic alterations, raised serum IgE, hypereosinophilia, alopecia and loss of eyebrows and eyelashes, enlarged lymph nodes and epatosplenomegaly; usually, signs and symptoms do not appear simultaneously and evolve with time [23]. - Therefore, mutations of the same gene can cause both typical SCID and Omenn syndrome but also various atypical clinical pictures and moreover slight immunological defects with later manifestations in adult age [36,37]. The variability of the clinical phenotypes is a common aspect of the genetic defects causing SCID [38], and it is observed also in siblings with the same mutation (interference of other genetic factors, environmental factors, etc.) [39,40]. In certain cases, clinical phenotypes are attenuated because of somatic mosaicism by spontaneous genetic reversion (correction of the mutation) in a somatic cellular line that then expands itself [41].

\section{Genotypes and clinical aspects of SCID}

With the exception of the complete DiGeorge anomaly and some cases of the Hoyeraal-Hreidarsson syndrome (autosomal dominant, AD), all forms of SCID are autosomal recessive (AR-SCID) or X-linked recessive (XLSCID) monogenic disorders.

An updated classification of SCID is based on underlying genetics and prevalent molecular pathogenetic mechanisms (Table 1).
SCID caused by impaired cytokine-mediated signaling Common gamma chain $(\gamma c)$ defect (OMIM, Online Mendelian Inheritance in Man, 300400)

Only male infants are affected by common gamma chain $(\gamma \mathrm{c})$ defect, XL $\mathrm{T}^{-} \mathrm{B}^{+} \mathrm{NK}^{-} \mathrm{SCID}$ caused by mutations of IL2RG gene, localized at Xq13.1 and encoding the $\gamma$ chain $(\gamma \mathrm{c})$ of interleukin-2 (IL-2) receptor. David Vetter (Figure 5; Figure 6) was affected by this SCID (his mutation: IL2RG nonsense exon 7 C937A S308X, -62 aa. of 369 aa.) [42-45]; the "bubble boy paradox" (IL-2 deficient knockout mice and the rare IL-2 deficient human patients do not have SCID but instead severe defect of $\mathrm{CD}^{+} \mathrm{T}_{\text {Reg }}$ lymphocytes and autoimmunity) was resolved by the discovery that IL-2 receptor $\gamma$ chain is shared (common $\gamma$ chain) by the receptors of IL-4, IL-7, IL-9, IL-15, and IL-21; IL-7 and IL-15 are essential for the development of $\mathrm{T}$ lymphocytes and NK cells, respectively $[46,47]$.

At least in the United States, this XL-SCID ("X-SCID") is the most frequent SCID; it is an exclusively immunological form except that also cutaneous keratinocytes express $\gamma \mathrm{c}$-dependent cytokine receptors and the associated JAK3 (see later), and these is necessary for the local innate immunity of keratinocytes against human papilloma virus (HPV); therefore, severe cutaneous HPV






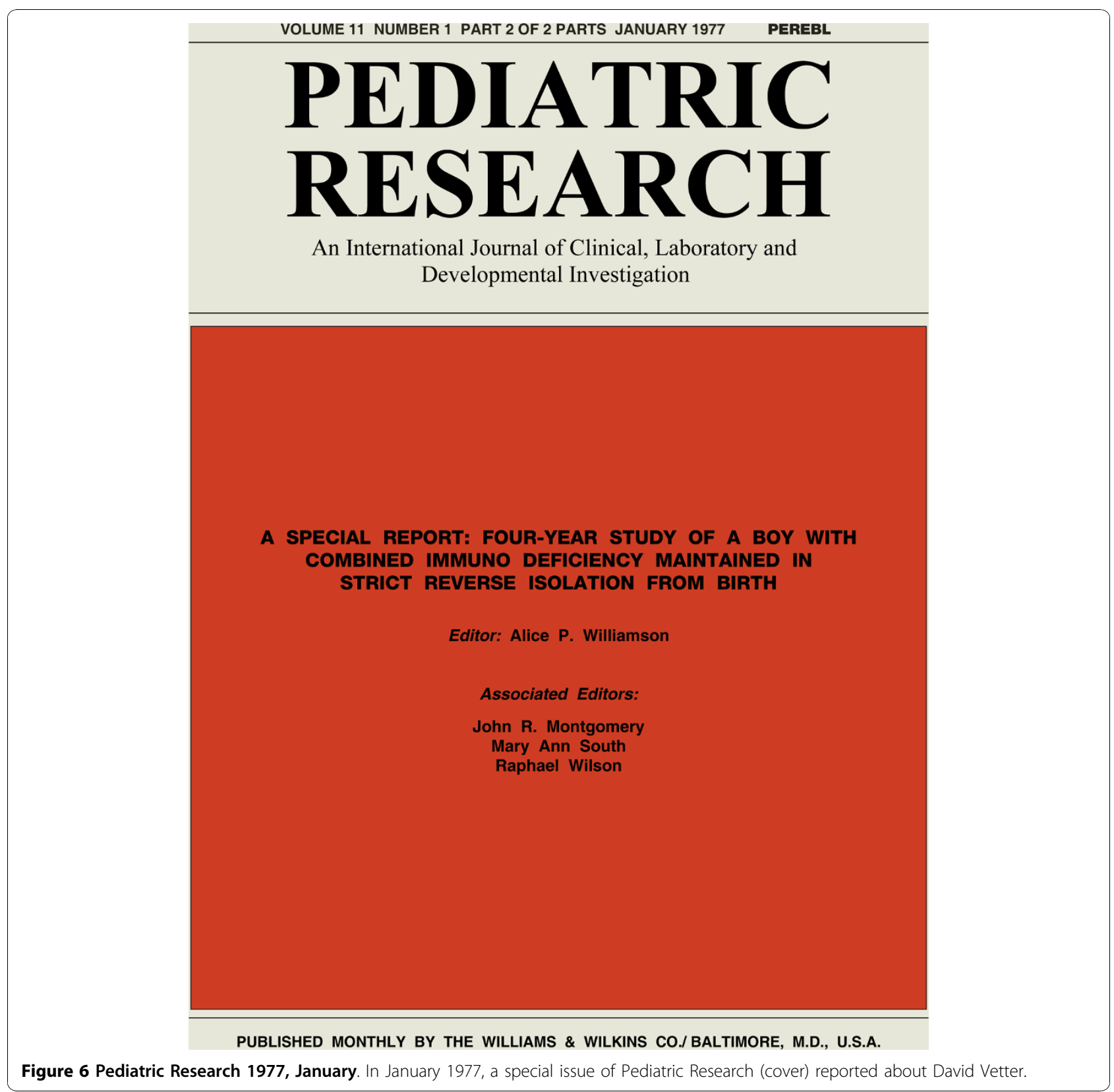

disease, including epidermodysplasia verruciformis, is a frequent late complications in common $\gamma_{c}$ (and JAK3) SCID patients many years after successful HSCT or gene therapy [48].

In X-SCID fully HLA-matched sibling or family donor HSCT without any conditioning is successful in $>95 \%$, however with frequent failure of donor B cell engraftment [49]. By contrast, history of gene therapy in $\mathrm{X}-\mathrm{SCID}$ is very controversial [50].

\section{JAK3 (Janus kinase 3) defect (OMIM 600802)}

JAK3 defect is the AR $\mathrm{T}^{-} \mathrm{B}^{+} \mathrm{NK}^{-} \mathrm{SCID}$ equivalent of the common $\gamma_{\mathrm{C}}$ defect X-SCID, since that JAK3 joins to $\gamma_{\mathrm{C}}$ in the $[\mathrm{IL}-2,4,7,9,15,21]$ - JAK3 - STAT5 signaling pathway $[47,51,52]$. Most JAK3 SCID patients are compound heterozygotes for two different mutations [5,51]. IL-7R $\alpha$ (IL-7 receptor alpha chain) defect (OMIM 608971)

IL-7R $\alpha$ defect is an AR $\mathrm{T}^{-} \mathrm{B}^{+} \mathrm{NK}^{+}$SCID because IL-15 function $(\longrightarrow$ NK cells) is normal and by contrast functions of IL-7 and of TSLP (thymic stromal lymphopoietin), that share the $\alpha$ chain in their receptors, are compromised $[47,53,54]$. In humans, IL-7 produced by stromal cells of lymphoid tissues and by hepatocytes is the true "T cell growth development factor" [55], and so its dosage in Guthrie card eluate is a complementary (respect to TRECs test) method for newborn SCID screening: blood IL-7 is increased "by feedback" if low 
T lymphocytes, and newborn IL-7 levels $>15 \mathrm{pg} / \mathrm{mL}$ indicate $\mathrm{T}^{-}$SCID [56]; note that IL-7 levels may be normal in $\mathrm{T}^{+}$or $\mathrm{T}^{++}$SCID (e.g., massive engraftment of maternal $\mathrm{T}$ lymphocytes, and Omenn syndrome; see before), and therefore TRECs test appears to be the best method for newborn SCID screening.

\section{SCID caused by pre-T cell receptor defects}

The pre-T cell receptor (pre-TCR), formed by a TCR $\beta$ chain (rearranged TCR $\beta$ gene) and by the disulfidelinked invariant pre-TCR $\alpha$ chain (pT $\alpha$ chain; codified by the PTCRA gene, localized at $6 \mathrm{p} 21.2$, and really a very suspect candidate gene for SCID) has an essential role during $\mathrm{T}$ lymphopoiesis in thymic microambient at the stage of large pre-T cell [57]. The pre-TCR also transmits its signal through numerous other molecules common to the TCR (T cell receptor of mature T lymphocytes): CD3 complex (CD3 $\gamma, \mathrm{CD} 3 \delta, \mathrm{CD} 3 \varepsilon, \mathrm{CD} 3 \zeta)$, protein-tyrosine kinases (e.g., Fyn, Lck, ZAP-70), protein-phosphotyrosine phosphatases (CD45, and others), etc. [58]

It is evident the similarity with the pre- $B$ cell receptor (pre-BCR) of B lymphopoiesis: defects of the pre-BCR (Ig $\mu, \lambda /$ VpreB, Ig $\alpha$, Ig $\beta$, Bruton tyrosine kinase BTK, B cell linker protein BLNK) cause arrest of the development of $B$ lymphocytes at the stage of large pre-B cell and therefore agammaglobulinemia [59]; defects of the pre-TCR, subdivided into 1) defects of $V(D) J$ recombination and 2) defects of signaling through the pre-T cell receptor, cause arrest of the development of $\mathrm{T}$ lymphocytes at the stage of large pre-T cell and therefore SCID (Figure 7).

\section{1) Defects of $V(D) J$ recombination}

The variable antigen-specific regions of the TCR $\beta$ chain of pre-TCR, Ig $\mu$ chain of pre-BCR and then TCR, BCR and Ig chains are encoded by the correspondent gene domains rearranged through the $V(D) J$ recombination of $D N A$ [60]. This recombination happens in two steps: $1^{\text {st }}$ step specific to $T$ and B lymphocytes (RAG1 and RAG2 "transposases", encoded by the "Recombination Activating Genes" RAG1 and RAG2); and $2^{\text {nd }}$ step due to the "Non-Homologous End-Joining" (NHEJ) proteins Ku70/80, DNA-PKcs, Artemis, Cernunnos/XLF, DNA ligase IV, XRCC4 - pathway, that repairs double-strand breaks in DNA in all living cells [61].

Defects of all these molecules cause $\mathrm{T}^{-} \mathrm{B}^{-} \mathrm{NK}^{+}$SCID because, again, note that contrary to $\mathrm{T}$ and $\mathrm{B}$ lymphocytes NK cells do not rearrange their germline DNA to produce genes encoding antigen-specific receptors. In defects of $1^{\text {st }}$ step (RAG1, RAG2), abnormalities are limited to $\mathrm{T}$ and $\mathrm{B}$ lymphocytes; by contrast, defects of $2^{\text {nd }}$ step (NHEJ) affect all cells and cause problems similar to other syndromes with DNA repair defects: cellular radiosensitivity, extreme toxicity by pre-HSCT conditioning (especially by alkylating agents and, obviously, by irradiation), predisposition to neoplasia, and (but only in some forms: defect of DNA ligase IV, defect of



Figure 7 Pre-TCR and pre-BCR. Schematic drawing of pre-T cell receptor (pre-TCR; thymus, large pre-T cell with rearranged TCR $\beta$ gene) and pre-B cell receptor (pre-BCR; bone marrow, large pre-B cell with rearranged IgH $\mu$ gene). Defects of the pre-TCR, subdivided into defects of V(D)J recombination and defects of signaling through the pre-T cell receptor, cause arrest of the development of T lymphocytes at the stage of large pre-T cell and therefore SCID; defects of the pre-BCR cause arrest of the development of B lymphocytes at the stage of large pre-B cell and therefore agammaglobulinemia. 
Cernunnos/XLF) dysmorphic facies, microcephaly, psychomotor delay [62].

RAG1 or RAG2 defect (OMIM 601457) RAG1 or RAG2 defect causes typical $\mathrm{T}^{-} \mathrm{B}^{-} \mathrm{NK}^{+}$SCID, Omenn syndrome, and also some rare peculiar forms: immunodeficiency with early onset of multivisceral and recurrent CMV infection, autoimmune cytopenia, restricted $\mathrm{T}$ cell repertoire with $\mathrm{TCR} \alpha \beta^{+}$lymphopenia and markedly expanded $\mathrm{TCR} \gamma \delta^{+} \mathrm{T}$ cells; immunodeficiency with extensive granulomatous disease involving the skin, mucous membranes and internal organs, and EBV-lymphoma; etc. [36,63]

In humans have been identified radiosensitive $\mathrm{T}^{-} \mathrm{B}^{-} \mathrm{NK}$ + SCID due to defects of four NHEJ molecules:

Artemis defect (OMIM 602450) Artemis defect, due to mutations of the DCLRE1C (DNA cross-link repair protein $1 C$ ) gene, is present with various mutations in all world populations; once it was known as "SCIDA", that is SCID of Athabascan-speaking Native Americans (Apache, Navajo), in which because of a founder effect 1 person every 10 is heterozygote for the mutation exon 8 C576A Artemis Y192X and 1 in 2,000 newborn is affected [64].

DNA ligase IV defect (OMIM 606593) DNA ligase IV defect causes the "Ligase IV syndrome" (phenotypically similar to the Nijmegen breakage syndrome, NBS) with possible typical SCID or Omenn syndrome, dysmorphic facies, microcephaly, growth retardation, psychomotor delay, skin anomalies, pancytopenia, and predisposition (also in heterozygotes) to leukemia and other neoplasia [65]. Cernunnos/XLF defect (OMIM 611291) Cernunnos/ XLF defect causes combined immunodeficiency (usually manifested later respect to typical SCID) with short stature, multiple dysmorphisms, microcephaly, psychomotor delay, bone marrow failure and myelodysplasia [66]. DNA-PKcs defect Recently in a girl from consanguineous parents of Turkish origin, diagnosed with AR $\mathrm{T}^{-}$ $\mathrm{B}^{-} \mathrm{NK}^{+}$SCID when she was 5-month-old, has been identified the first human case of DNA-PKcs (DNA-dependent Protein Kinase catalytic subunit) defect, due to a homozygous missense mutation (T9185C L3062R) of the coding gene PRKDC (OMIM 600899). It was known since many years that mutations of PRKDC (Protein kinase, DNA-activated, catalytic polypeptide) gene cause the naturally occurring SCID in mice, Arabian foals and Jack Russell terriers; so, DNA-PKcs defect has been long predicted in human SCID and finally found. Note that the $P R K D C$ gene includes 86 exons (very cumbersome sequencing), and that the expression of DNA-PKcs protein, composed by 4096 aminoacids, can be normal but with defect of function [67].

HSCT is particularly problematic in all SCID caused by defects of $\mathrm{V}(\mathrm{D}) \mathrm{J}$ recombination, especially if radiosensitive (see later).

\section{2) Defects of signaling through the pre-T cell receptor} $C D 3 \delta, C D 3 \varepsilon, C D 3 \zeta$ or $C D 3 \gamma$ defect (OMIM 608971; 608971; 610163; 186830) Complete CD3 $\delta, \mathrm{CD} 3 \varepsilon, \mathrm{CD} 3 \zeta$ or CD3 $\gamma$ defect can cause AR $\mathrm{T}^{-} \mathrm{B}^{+} \mathrm{NK}^{+} \mathrm{SCID}$ (about $1 \%$ of SCID): the different CD3 subunits, organized as $\gamma \varepsilon, \delta \varepsilon$ and $\zeta \zeta$ dimers, join to pre-TCR and then TCR and are essential for their assemblage in cell membrane and signal transmission and therefore thymic $\mathrm{T}$ lymphopoiesis and mature $\mathrm{T}$ lymphocyte activation; defects cause differently severe phenotypes $[68,69]$.

CD45 defect (OMIM 608971) Very rare is also the AR $\mathrm{T}^{-} \mathrm{B}^{+} \mathrm{NK}^{+/-}$SCID caused by CD45 defect [70]: CD45 (LCA, Leucocyte Common Antigen) is a protein-phosphotyrosine phosphatase essential for pre-TCR and TCR (and BCR also) signaling, constitutes about 10\% of the proteins of $\mathrm{T}$ and $\mathrm{B}$ lymphocyte membrane, and exists in multiple isoforms produced by complex alternative splicing of the exons encoding its extracellular domains. The expression of the different CD45 isoforms depends on cell type and state of differentiation and activation (e.g., naïve $\mathrm{CD} 4^{+} C D 45 R A^{+} \mathrm{T}$ cells, and memory $\mathrm{CD} 4$ ${ }^{+} C D 45 R O^{+} \mathrm{T}$ cells); it is also very interesting the association between $\mathrm{CD} 45$ polymorphisms and susceptibility or resistance to infective or autoimmune diseases [71].

ZAP-70 defect (OMIM 176947) ZAP-70 defect causes a characteristic deficiency of $\mathrm{CD} 8^{+} \mathrm{T}$ lymphocytes, manifested as $\mathrm{AR} \mathrm{T}^{+}\left(\mathrm{CD}_{4}^{+} \mathrm{CD}^{-}\right) \mathrm{B}^{+} \mathrm{NK}^{+} \mathrm{SCID}$ or as less severe phenotypes $[16,72]$.

p56lck defect A single case of $\mathrm{AR} \mathrm{T}^{-} \mathrm{B}^{+} \mathrm{NK}^{+} \mathrm{SCID}$ caused by p56lck defect has been reported (not identified mutation, but aberrant splicing with exon 7 absence in the transcribed mRNA and very reduced protein expression) [73]; p56lck (OMIM 153390) defective activity has been also observed in adults with idiopathic CD4 lymphopenia [74].

\section{SCID caused by increased lymphocyte apoptosis Reticular dysgenesis (RD) (OMIM 267500)}

Reticular dysgenesis associates $\mathrm{AR} \mathrm{T}^{-} \mathrm{B}^{-} \mathrm{NK}^{-} \mathrm{SCID}$ and severe congenital neutropenia (arrest of myeloid maturation at the promyelocyte stage) with total leukocytes $<400 / \mu \mathrm{L}$ ("aleukocytosis"), fatal neonatal sepsis, no response to granulocyte colony-stimulating factor (GCSF), and severe sensorineural deafness in babies surviving after successful HSCT. RD is caused by mutations (missense mutations; deletions) of the $A K 2$ gene, encoding the mitochondrial enzyme adenylate kinase 2 (AK2) $[75,76]$. Adenylate kinases (AK) catalyze the reversible transfer of a phosphoryl group from adenosine triphosphate to adenosine monophosphate: 2 ADPs $<==>$ ATP + AMP; from bacteria to humans, every cell survives only if ATP/ADP/AMP concentrations maintained within very narrow and tightly regulated ranges [77]. Seven different AK isozymes exist in human cells, with 
different tissue and subcellular distribution: AK1 (cytosol) and AK2-AK3-AK4 (mitochondrial) are present in all cells except for blood nucleated cells and cells of stria vascularis in the inner ear, that express only AK2. AK2 is located in the mitochondrial intermembrane space, the same as HAX-1 whose defect causes Severe Congenital Neutropenia of the families originally described by Kostmann [78].

\section{Adenosine deaminase deficiency (ADA-SCID) (OMIM 102700)}

The purine salvage enzyme adenosine deaminase (ADA) catalyzes the irreversible deamination of adenosine (Ado) and 2-deoxyadenosine (dAdo) to inosine and to deoxyinosine, respectively, and its deficiency results in "metabolic poisoning" from accumulation of Ado, dAdo and deoxyadenosine triphosphate (dATP). Excess intracellular dAdo and dATP cause generalized lymphocyte apoptosis ( $\left.\rightarrow \mathrm{T}^{-} \mathrm{B}^{-} \mathrm{NK}^{-} \mathrm{SCID}\right)$, while excess extracellular Ado (normally produced by $\mathrm{CD}_{4}^{+} \mathrm{T}_{\text {Reg }}$ lymphocytes) acts on specific receptors with further lymphocyte inhibition [79] and might be important for frequent manifestations of immune dysregulation and autoimmunity (type I diabetes, hypothyroidism, autoimmune thrombocytopenia, hemolytic anemia) also reported in ADASCID patients treated by HSCT or gene therapy [80]. In humans the highest ADA enzyme activity is found in lymphocytes, particularly in intrathymic immature $\mathrm{T}$ cells, but ADA is an ubiquitous "housekeeping" enzyme present in all cell types; therefore, ADA deficiency is a 'systemic' metabolic disorder causing SCID as well as several nonimmunological abnormalities: alterations of the ribs (costochondral junctions), vertebral bodies, iliac crests and other skeletal segments [81]; neonatal hepatitis; renal and lung abnormalities; sensorineural deafness; neurological anomalies (cognitive, motor and behavioral problems) with a poor prognosis also after the correction of the immune defect [82]. IQ $<-2$ SD correlates with dATP levels at diagnosis; also note that the isolated genetic deficiency of the enzyme S-adenosyl homocysteine hydrolase (SAHH), inhibited by Ado, causes severe psychomotor delay [83].

Really, different therapeutic options exist for the treatment of ADA-SCID [84,85]:

- fully HLA-matched sibling or family donor HSCT without any conditioning is the treatment of choice, with success $>90 \%$; at present, data from matched unrelated donor HSCT are not conclusive; by contrast, mismatched HSC transplants (parental haploidentical donor; mismatched unrelated donor), both without conditioning and with myeloablative or reduced-intensity conditioning, have poor chance of success and should be avoided;

- enzyme replacement therapy (ERT): weekly or twice-weekly intramuscular injection of PEG-ADA (polyethylene-glycol-modified calf intestinal ADA) protects from "metabolic poisoning" both lymphocytes (restoring immune function within 2 to 4 months) and other cells, and it is often life-saving therapy at diagnosis; ERT gives an overall $80 \%$ probability of surviving at 20 years; in the remaining $20 \%$ of patients, early mortality (within 6 months) results from serious conditions already present at diagnosis, late mortality from refractory hemolytic anemia, chronic respiratory insufficiency, lymphoproliferative disorders, liver malignancies; note that long-term (810 years) PEG-ADA treated patients show a gradual decline of thymic function and $\mathrm{T}$ cell counts;

- autologous HSC gene therapy (GT): as described recently $[85,86]$, gene therapy had in ADA-SCID patients the most promising results.

\section{Purine nucleoside phosphorylase (PNP) deficiency (OMIM} 613179)

Purine nucleoside phosphorylase (PNP) follows ADA in the purine salvage pathway, and PNP deficiency also causes SCID (excess deoxyguanosine and deoxyguanosine triphosphate cause apoptosis of lymphocytes, mainly immature T lymphocytes). Note that PNP deficient cells do not produce uric acid, and therefore low uric acid in serum $(<2 \mathrm{mg} / \mathrm{dL}$, usually $<1 \mathrm{mg} / \mathrm{dL})$ supports the diagnosis. PNP deficiency has a poor prognosis [87]: PEG-PNP is not commercialized, and gene therapy is still experimental in mice; HSCT is the only therapy, but it does not correct the severe neurological problems usually present (hypertonia, hypotonia, ataxia, psychomotor delay); autoimmunity (hemolytic anemia, autoimmune thrombocytopenia, neutropenia, arthritis, etc.) and neoplasia are also frequent.

\section{SCID caused by defects in thymus embryogenesis}

Thymocytes cannot develop to normal mature $\mathrm{T}$ lymphocytes without cross-talk with thymic cells (thymic epithelial cells, TECs; thymic stromal cells; thymic medullary dendritic cells) $[88,89]$; two forms of SCID recognize a primary embryonic thymic defect:

Nude/SCID Syndrome (OMIM 601705)

The gene WHN (wingled helix naked) encodes the FOXN1 (forkhead box N 1) transcription factor selectively expressed in thymic epithelia and skin, and its mutations cause the mouse Nude/SCID phenotype and also the equivalent human Nude/SCID syndrome (congenital total alopecia, and absence of the thymus with $\left.\mathrm{AR} \mathrm{T}^{-} \mathrm{B}^{+} \mathrm{NK}^{+} \mathrm{SCID}\right)[29,90]$. The human form has been first identified in two sisters of a small Italian village, Acerno, where because of a founder effect the $6.52 \%$ of inhabitants are heterozygous carriers of the mutation exon 5 C792T R255X [91]. FOXN1 appears also essential for the embryonic development of the neural tube: an affected fetus, with absence of thymus and abnormal 
skin, showed also anencephaly and spina bifida; and, in the village there is a high rate of abortions in the first trimester in the marriages between heterozygous for the FOXN1 mutation [92].

\section{Complete DiGeorge anomaly}

Complete DiGeorge anomaly, characterized by absence of the thymus with consequent $\mathrm{T}^{-} \mathrm{B}^{+} \mathrm{NK}^{+} \mathrm{SCID}$ and variously associated facial dismorphy, congenital heart disease (conotruncal malformations), and neonatal hypocalcemia by defect of parathyroid glands, has different etiologies [93]:

- approximately 50\%: DiGeorge Syndrome (OMIM 188400) [94] by 22q11.2 deletion of about $3 \mathrm{Mb}$ interesting $>35$ genes, among which the TBX-1 (Tbox 1) gene involved in the development of heart, thymus, parathyroid glands, palate, face; note that the vast majority of infants with DiGeorge syndrome have "partial" DiGeorge anomaly, with low T cell counts but not the immunodeficiency of complete DiGeorge anomaly;

- about 25\%: CHARGE association (coloboma, heart defects, atresia choanae, retardated growth and development, genital hypoplasia, ear anomalies/deafness; OMIM 214800), with in the majority of patients mutation of the CHD7 gene, encoding the chromodomain helicase DNA-binding protein-7 $[95,96]$;

- about 15\%: diabetic mother embryopathy [97].

22q11.2 deletion and CHD7 mutation have autosomal dominant transmission, with de novo mutation in more than $80 \%$ of cases; in around $1 / 3$ of the cases, SCID manifests as Omenn syndrome ("atypical" complete DiGeorge anomaly).

These children have normal hematopoietic stem cells that cannot develop to mature $\mathrm{T}$ lymphocytes because of the absence of thymic stroma and epithelium; so, the specific treatment of thymic aplasia is thymus transplant: neonatal thymus took during newborn heart surgery and cultured in vitro to eliminate the HLA not-matched thymocytes, and then insertion of multiple slides containing thymic epithelium (that is, surprisingly, functionally not HLA-restricted) into the quadriceps muscle of the SCID infant [98]. However, thymus transplant is a technically very demanding procedure, and there is only one center in the United States (Duke University Medical Center, Durham, NC 27710, USA) that is currently able to accomplish it [99]. Alternatively, a satisfactory $\mathrm{T}$ cell immunity may also be obtained in these children by the adoptive transfer of HLA identical expanding and longlasting $T$ lymphocytes present in simple peripheral blood mononuclear cells (PBMC), bone marrow, or cord blood of a fully HLA-matched donor [100].

\section{SCID caused by impaired calcium flux} ORAI1 defect-STIM defect

The variations of intracellular $\mathrm{Ca}^{2+}$ levels are a fundamental mechanism for the signal transduction in all living cells [101]. In T lymphocytes, the activation of the TCR/CD3 complex causes a release of intracellular $\mathrm{Ca}^{2+}$ from the endoplasmic reticulum (ER) stores, followed by a "store operated $\mathrm{Ca}^{2+}$ entry" (SOCE) that is a conspicuous influx into the cell of other $\mathrm{Ca}^{2+}$ ions from extracellular space because of opening of the $\mathrm{Ca}^{2+}$ release-activated calcium channels (CRAC) of the cell membrane; a main final effect of intracellular $\mathrm{Ca}^{2+}$ increase is translocation of NFAT (nuclear factor of activated $\mathrm{T}$ cells) into the nucleus, with activation of specific genes.

In rare $\mathrm{AR} \mathrm{T}^{+} \mathrm{B}^{+} \mathrm{NK}^{+} \mathrm{SCID}$ patients has been identified a SOCE-CRAC defect, caused by mutations in genes encoding two highly conserved proteins: ORAI1 (subunit forming pores in CRAC; its name comes from ORAI, the three sisters of Greek mythology), and STIM1 (stromal interaction molecule-1; it is the sensor of $\mathrm{Ca}^{2+}$ levels in ER and the activator of ORAI1-CRAC).

The clinical phenotypes of the ORAI1 defect (OMIM 612782) and of the STIM defect (OMIM 612783) are similar [15]: serious $\mathrm{AR} \mathrm{T}^{+} \mathrm{B}^{+} \mathrm{NK}^{+} \mathrm{SCID}$, with normal $\mathrm{T}$, $B$ and NK cell differentiation and counts but severe $T$ lymphocyte defect of $\mathrm{Ca}^{2+}$ influx and of proliferation after mitogen stimulation, ipergammaglobulinemia but with deficiency of specific antibody production, congenital non-progressive global myopathy (hypotonic infant), ectodermal dysplasia (anhydrosis, defects in the formation of dental enamel). In the STIM1 defect there is also $\mathrm{CD} 4{ }^{+} \mathrm{T}_{\mathrm{Reg}}$ lymphocyte deficiency, with severe autoimmunity (autoimmune thrombocytopenia, hemolytic anemia), enlarged lymph nodes and epatosplenomegaly.

\section{SCID caused by other mechanisms \\ Coronin-1A defect}

Mice with a homozygous missense mutation in the Coronin-1A (CORO1A) gene show severe T cell lymphopenia; this has suggested the recent discovery of the absence of Coronin-1A in a 13-month-old girl with AR $\mathrm{T}^{-} \mathrm{B}^{+} \mathrm{NK}^{+}$SCID, by deletion of the entire CORO1A gene on one allele (600 kbs deletion in 16p11.2) and a dinucleotide deletion resulting in frameshift and premature termination on the other allele [102,103]. Coronins (1A, $1 \mathrm{~B}, 1 \mathrm{C}, 2 \mathrm{~A}, 2 \mathrm{~B}, 7)$ are a highly conserved family of proteins, regulators of cell F-actin structures, cytoskeletal rearrangements and intracellular membrane transport; they, by contrast to WASP (Wiskott-Aldrich Syndrome Protein) antagonize actin polymerization. Coronin-1A (OMIM 605000) is especially expressed in T cells, and its defect causes an excess of F-actinin in the cortex thymocytes with drastically impaired cell movement, intrathymic retention of single positive $\mathrm{CD} 4^{+} \mathrm{CD} 8^{-}$or 
$\mathrm{CD}^{-} \mathrm{CD}^{+}$mature $\mathrm{T}$ lymphocytes, and severe peripheral T lymphopenia [104].

\section{MHC Class II (MHCII) defect (OMIM 209920)}

The genes CIITA, RFXANK, RFX5, RFXAP encode four factors that regulate promoters and transcription of the HLA DR, DP, DQ cluster, localized at 6p21.3; their mutations cause absence of Major histocompatibility complex class II (MHCII) molecules, normally expressed at cell surface by thymic epithelial cells, activated T lymphocytes, and cells (B lymphocytes, dendritic cells, monocytes/macrophages) that present antigens to $\mathrm{CD} 4^{+}$ T lymphocytes. Apart from a minority of "attenuated" cases, typical MHC class II deficiency causes a serious $\mathrm{AR} \mathrm{T}^{+}\left(\mathrm{CD} 4{ }^{-} \mathrm{CD}^{+}\right) \mathrm{B}^{+} \mathrm{NK}^{+} \mathrm{SCID}$ with a poor prognosis and overall cure rate $<50 \%$ also by HSCT from familial HLA-matched donor. HSCT in these patients is complicated by a high incidence of acute GvHD associated with preexisting viral infections, and it is highly recommended that HSCT be performed in young children $(<$ 2 years), using either an HLA-identical sibling or the best available compatible donor [105].

\section{$\mathrm{CHH}$ (Cartilage hair hypoplasia) (OMIM 250250)}

Mutations of the highly polymorphic $R M R P$ (ribonuclease mitochondrial RNA processing) gene, encoding not a protein but the 267-nucleotide-long $R N A$ component of the mitochondrial RNA-processing endonuclease (a multiprotein RNA complex with at least ten different proteins) cause defects in ribosomal RNA processing and mitochondrial and cellular replication, and a heterogeneous phenotypic spectrum [37]. Cartilage hair hypoplasia, particularly frequent in the Amish and the Finnish populations (respectively $1: 19$ and 1:76 individuals carriers of the mutation g.70 $\mathrm{A}>\mathrm{G}$, because of a founder effect) is a metaphyseal chondrodysplasia with shortlimbed dwarfism, light-colored hypoplastic hair, and variable immunodeficiency: AR $\mathrm{T}^{-} \mathrm{B}^{+} \mathrm{NK}^{+} \mathrm{SCID}$ (also manifested as Omenn syndrome), selective $\mathrm{CD}^{+} \mathrm{T}$ lymphopenia, or even not relevant immunologic defects; patients with combined immunodeficiency without skeletal alterations have also been reported. Apart from $\mathrm{CHH}$, mutations of RMRP (usually in different nucleotides of the RNA molecule) cause other three skeletal disorders: metaphyseal dysplasia without hypotrichosis (MDWH), kyphomelic dysplasia, and anauxetic dysplasia.

Hoyeraal-Hreidarsson Syndrome (HHS) (OMIM 300240)

Hoyeraal-Hreidarsson syndrome (HHS), characterized by telomerase defect and by the pathognomonic association of $\mathrm{T}^{+} \mathrm{B}^{-} \mathrm{NK}^{-}$SCID and cerebellar hypoplasia (Figure 8 ), is the severe infantile variant of dyskeratosis congenita $[17,106]$. Defective telomerase activity affects all tissues in constant renewal (bone marrow, skin, oral and gut epithelium, lung alveolar epithelium, etc.) and also development, differentiation and activation of lymphocytes; it also causes extreme toxicity by pre-HSCT conditioning

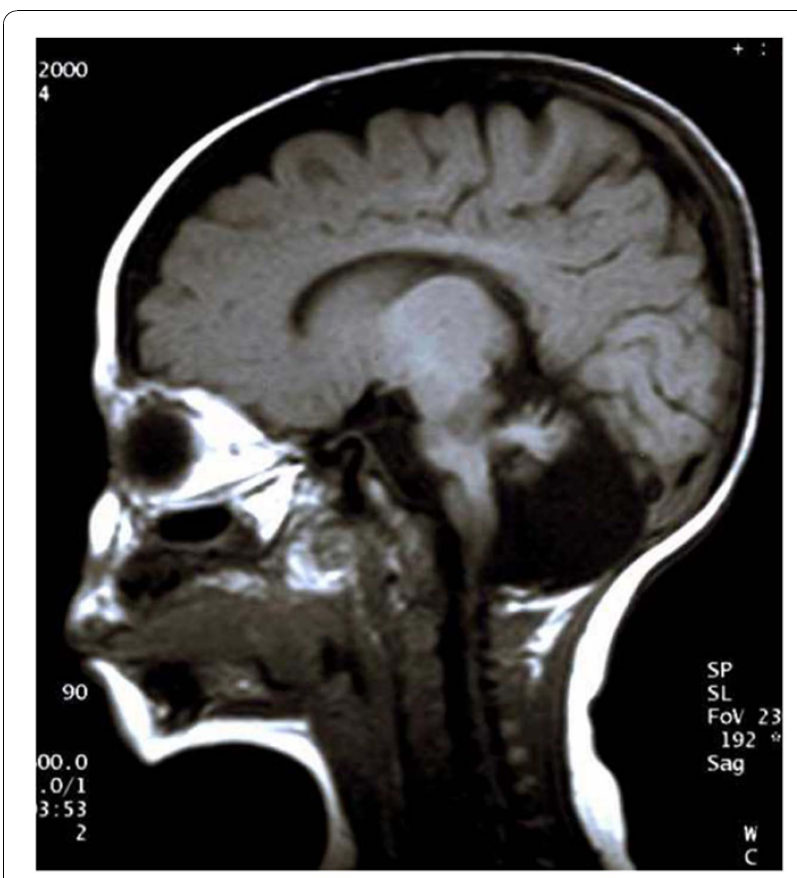

Figure 8 Hoyeraal-Hreidarsson Syndrome. Cerebellar hypoplasia in a Sardinian 6-month-old male with $\mathrm{T}^{+} \mathrm{B}^{-} \mathrm{NK}^{-}$SCID; missense mutation of DKC1 gene encoding dyskerin (X-linked HoyeraalHreidarsson syndrome).

(especially by alkylating agents and by irradiation), similar to defects of NHEJ.

XL-HHS and the "classical" X-linked dyskeratosis congenita (XL-DC) affect only males and are due to mutations of the $D K C 1$ gene within $\mathrm{Xq} 28$, encoding dyskerin, a component of telomerase [17]. Various other genetic defects cause HHS both in male and female infants: ARHHS by homozygous mutations of the TERT gene encoding telomerase reverse-transcriptase [107]; ADHHS by heterozygous mutations of the TINF2 gene encoding TIN2 (TRF1-interacting nuclear protein 2), one of the components (six proteins) of the shelterin telomere protection complex [108,109]; and AD-HHS by heterozygous mutation of DCLRE1B (DNA cross-link repair protein $1 \mathrm{~B}$ ) gene, encoding Apollo, a DNA repair factor interacting with the shelterin complex (mutation recently identified by Revy et al. in the HHS female infant described by them ten years ago) [110,111].

Hereditary folate malabsorption (HFM) (OMIM 229050)

Hereditary folate malabsorption (HFM) is due to proton-coupled folate transporter (PCFT) gene mutations and consequent folate malabsorption in the duodenum and upper jejunum, with depletion of transplacentally acquired stores at 3-4 months of age; PCFT also transports folate through choroid plexus into the cerebrospinal fluid. Lymphocytes and developing nervous system are particularly sensitive to the defective thymidine 
synthesis and resulting DNA instability caused by folate deficiency. Affected infants show failure to thrive, diarrhea, anemia (megaloblastic, but masked to normocytic if associated iron deficiency), infections, hypogammaglobulinemia and an $\mathrm{AR} \mathrm{T}^{+} \mathrm{B}^{+} \mathrm{NK}^{+} \mathrm{SCID}$ phenotype; they also present seizures and, if not treated promptly, severe neurodevelopmental defects. Serum and cerebrospinal fluid folate levels are undetectable.

This is a special reversible SCID: parenteral folate repletion causes a dramatic recovery of immunodeficiency and, if prompt and aggressive, prevents irreversible neurological damages [112].

\section{Hematopoietic stem cell transplantation (HSCT)}

SCID can be successfully treated by HSCT, the only curative option for most affected infants; several recent papers [113-116] report on survival and long-term outcome in several hundreds of patients over the last decades, with a success rate ranging from 70-95 percent and varying incidence of adverse effects and complications.

Main variables influence the outcome of HSCT [117]:

- Age and clinical condition at the time of diagnosis and of HSCT: there is an always increasing evidence of best outcome if diagnosis and HSCT performed in the first few months of life (1-4 months), before clinical presentation with infections and failure to thrive; of course, this underlines the importance of population-based newborn screening for SCID, that permits the early diagnosis of asymptomatic newborns.

- HSC donor: unfortunately, only a minority of SCID infants have an HLA-matched sibling, obviously the ideal donor; for infants without a matched related donor, alternative donors are an HLA-matched unrelated volunteer or an HLAmatched unrelated banked cord blood unit, or, if none of these is available in a very short time, rigorously $\mathrm{T}$-depleted haploidentical related (mother or father) bone marrow or peripheral blood stem cells (PBSC).

- No conditioning versus conditioning regimen, and SCID genotype/phenotype: HSCT engraftment without any pretransplant conditioning regimen is theoretically possible in most SCID infants, especially if $\mathrm{NK}^{-}$SCID (e.g., ADA-SCID, common $\gamma \mathrm{c}$ defect, JAK3 defect), but with frequently defective donor B cell reconstitution and so persistent B cell deficiency that requires long-term (for the rest of life) immunoglobulin replacement therapy. New, now in use, cytoreductive nonmyeloablative regimens, particularly those including fludarabine, appear safe and causing a reduced toxicity and presumably reduced long-term effects on for example growth and endocrine system: therefore they are probably recommended, if possible, also in all these very young (few months of age) children [118].

In SCID infants with V(D)J recombination - DNA repair defects (especially NHEJ defects) the molecular problem causes cellular radiosensitivity and extreme toxicity by "historical" pretransplant conditioning regimen (especially by alkylating agents and, obviously, by irradiation); the same is true in patients with telomerase defect (Hoyeraal-Hreidarsson syndrome and also its "later" form, classical dyskeratosis congenita).

Not only because of the different sensitivity to conditioning regimen, SCID genotype/phenotype influence the outcome of HSCT: e.g., a better outcome is usual in SCID with common $\gamma$ c or JAK3 defect (a part from frequent cutaneous HPV) and IL-7R $\alpha$ defect; on the contrary, a complicated outcome is more frequent in SCID with $\mathrm{V}(\mathrm{D}) \mathrm{J}$ recombination - DNA repair defects (high risk of conditioning toxicity, obviously if not "diseasespecific" strategy for nonmyeloablative regimen; and, also if normal immunologic reconstitution, frequent autoimmunity, gut problems, etc.) and in ADA-SCID (frequent neurological anomalies: cognitive, motor and behaviour problems) with a poor prognosis also after the correction of the immune defect.

\section{Gene Therapy (GT)}

Gene therapy, i.e., the insertion of normal gene through a vector virus (e.g., defective Moloney murine leukemia virus, M-MLV) into DNA of autologous $\mathrm{CD}^{+} 4^{+}$hematopoietic stem cells, progenitors also of lymphocytes, had practical application in two forms of SCID with different results $[50,86,119,120]$.

- Beginning in 1999 in Paris and in 2001 in London two European groups performed gene therapy for treating common $\gamma \mathbf{c}$ defect XL-SCID in respectively 11 and 10 children, aged from 1 to 33 months; 17 of 21 children had satisfactory $\mathrm{T}$ cell reconstitution, and 12 of them had also normal $\mathrm{B}$ cell reconstitution with no more need for immunoglobulin replacement therapy. Unfortunately, 5 children (4 in Paris, 1 in London) at 24-68 months from gene therapy developed an acute lymphoblastic leukemia (ALL) mainly because complex mutagenesis started with the insertion at $11 \mathrm{p} 13$ of a single copy of the defective retrovirus, containing the normal IL2RG gene but also its enhancer, near the promoter of LMO2 (LIM domain only 2 ), known oncogene of $\mathrm{T}$ lymphocytes then aberrantly transcribed and expressed (insertional mutagenesis) $[121,122]$. One child was dead from 
leukemia, the others were cured by chemotherapy; the occurrence of this serious complication led to stop of gene therapy for common $\gamma c$ defect XL-SCID in Europe. In the United States a gene therapy trial, now closed for new patients, recluted 8 patients already treated unsuccessfully with allogeneic HSCT: in the first 3 patients (aged 10-14 years), immunological recovery has been poor, probably due to agerelated thymic involution and chronic viral infections.

- Gene therapy had very good results in ADA-SCID children, and it is really indicated in ADA-SCID patients without an HLA-matched related donor, as particularly described in the 15 patients (age at GT 6 months - 5.6 years) of the casistic of Aiuti et al. [86]. Aiuti used an ameliorated transduction protocol of CD34 ${ }^{+}$autologous stem cells by a defective MLV vector, nonmyeloablative conditioning (busulfan $2 \mathrm{mg} / \mathrm{kg}$ ev at days -3 and -2) to create space in the bone marrow, and stopping of PEG-ADA treatment to give a selective proliferative vantage to lymphocytes with corrected gene. All 15 patients are alive, with in the first 10 treated patients: good immunological recovery in $9 / 10$, persistent expression of ADA with "systemic detoxification" without any more need for PEG-ADA until 8 years since gene therapy in $8 / 10$, and no more need for immunoglobulin replacement therapy in 5/10. Similar results have been reported in patients treated by other groups. Especially, in no patient has been reported the complication of the clonal leukemic proliferation because of insertional mutagenesis, and this also if the viral vector however inserts itself dangerously in proximity of LMO2 or other known oncogenes.

There is now an intense research for different viral vectors that do not present problems of insertional mutagenesis: SIN (self-inactivating) Lentiviruses integrate also in the cells not in mitosis, and (on the contrary of gammaretrovirus such as MLV) do not have as preferential integration site the promoter regions of active (expressed) genes [123]. The recent report of a clonal expansion from integration of Lentivirus vector in the DNA-binding protein HMGA2 (high mobility group AT-hook 2) gene in a patient of the gene therapy trial for thalassemia in France [124] imposes however further caution.

\section{Conclusions}

More than thirty identified genetic defects cause human SCID and certainly novel genes and molecular mechanisms will be discovered over the next few years, maybe between function-based candidate genes (e.g., PTCRA gene encoding the invariant pre-TCR $\alpha$ chain; genes encoding scaffold proteins involved in immune signaling; genes encoding DNA repair proteins).

Human SCID is always a prenatal disorder of T lymphocyte development: it is already present at birth even if clinically silent in most affected newborns, therefore the universal newborn screening for SCID (as started in Wisconsin) is really of great practical importance. If not identified at birth, SCID manifests itself in the first few months of life as typical lymphopenic $\mathrm{T}^{-}$SCID or atypical $\mathrm{T}^{+} / \mathrm{T}^{++}$SCID (especially Omenn syndrome), but always as a pediatric emergency. Essentially every affected infant could be cured by very early diagnosis, prompt prevention (sterile rooms!) and treatment of infections, and timely hematopoietic stem cell transplantation (or, if ADA deficiency, gene therapy or enzyme replacement therapy). Knowledge of the different genetic and clinical forms of SCID is essential for the most accurate approach to diagnosis and treatment as well to family counseling.

\section{Consent}

Written informed consent was obtained from the parents of the infants for publication of images and clinical data in Figure 3, Figure 4 and Figure 8. A copy of the written consent is available for review by the Editor-inChief of this journal.

\section{Acknowledgements}

I am very grateful to all the Sardinian patients and families for their participation, interest and support in the study of SCID. I thank all my colleagues, nurses and laboratory personnel at my Pediatric Clinic and other Hospitals for their valuable and essential work. I am deeply thankful to Dr. Manuela Badiali, biologist in my laboratory, who studied immunology and molecular biology of patients, and to Prof. Anna Villa and Dario Strina PhD (Milan) and to Prof. Inderjeet Dokal, Tom J. Vulliamy PhD and Anna Marrone $\mathrm{PhD}$ (London) who respectively identified DCLRE1C and DKC1 mutations in my patients. I am sincerely grateful to my Prof. Antonio Cao, extraordinary researcher and teacher in Pediatrics and Genetics.

\section{Author's information}

Pediatric HSCT Unit, 2^ Pediatric Clinic of University, Ospedale Microcitemico, Via Jenner s/n, 09121 Cagliari, Sardinia, Italy.

\section{Competing interests}

The author declares that he has no competing interests.

Received: 31 October 2010 Accepted: 15 November 2010 Published: 15 November 2010

\section{References}

1. Cossu F: Le basi genetiche delle SCID. Prospettive in Pediatria 2009, 156:228-238.

2. Ochs HD, Smith CIE, Puck J: Primary Immunodeficiency Diseases: A Molecular and Genetic Approach New York: Oxford University Press; 2007.

3. Stiehm ER, Ochs HD, Winkelstein JA: Immunologic disorders in infants \& children Philadelphia, Pennsylvania: Elsevier Saunders; 2004.

4. Baker MW, Laessig RH, Katcher ML, Routes JM, Grossman WJ, Verbsky J, Kurtycz DF, Brokopp CD: Implementing routine testing for severe combined immunodeficiency within Wisconsin's newborn screening 
program. Public Health Rep 2010, 125(Suppl 2):88-95[http://www. publichealthreports.org/archives/issueopen.cfm?articleID=2428].

5. Hale JE, Bonilla FA, Pai SY, Gerstel-Thompson JL, Notarangelo LD, Eaton RB, Comeau AM: Identification of an infant with severe combined immunodeficiency by newborn screening. J Allergy Clin Immunol 2010, 126:1073-1074.

6. SCID added to national newborn screening standards. Am I Med Genet A 2010, 152A(8):ix.

7. Rosen FS: Severe combined immunodeficiency: a pediatric emergency. J Pediatr 1997, 130:345-346.

8. Patel NC, Hertel PM, Estes MK, de la Morena M, Petru AM, Noroski LM Revell PA, Hanson IC, Paul ME, Rosenblatt HM, Abramson SL: Vaccineacquired rotavirus in infants with severe combined immunodeficiency. $N$ Engl J Med 2010, 362:314-319.

9. Centers for Disease Control and Prevention (CDC): Addition of severe combined immunodeficiency as a contraindication for administration of rotavirus vaccine. MMWR Morb Mortal Wkly Rep 2010, 59:687-688.

10. Mold JE, Michaëlsson J, Burt TD, Muench MO, Beckerman KP, Busch MP, Lee TH, Nixon DF, McCune JM: Maternal alloantigens promote the development of tolerogenic fetal regulatory T cells in utero. Science 2008, 322:1562-1565

11. Muench MO: In utero transplantation: baby steps towards an effective therapy. Bone Marrow Transplant 2005, 35:537-547.

12. Bluestone JA, Mackay CR, O'Shea JJ, Stockinger B: The functional plasticity of T cell subsets. Nat Rev Immunol 2009, 9:811-816.

13. Wan YY: Multi-tasking of helper T cells. Immunology 2010, 130:166-171

14. Adeli MM, Buckley RH: Why newborn screening for severe combined immunodeficiency is essential: a case report. Pediatrics 2010, 126: e465-e469.

15. Feske S, Picard C, Fischer A: Immunodeficiency due to mutations in ORAl1 and STIM1. Clin Immunol 2010, 135:169-182.

16. Turul T, Tezcan I, Artac H, de Bruin-Versteeg S, Barendregt BH, Reisli I, Sanal O, van Dongen JJ, van der Burg M: Clinical heterogeneity can hamper the diagnosis of patients with ZAP70 deficiency. Eur J Pediatr 2009, 168:87-93.

17. Cossu F, Vulliamy TJ, Marrone A, Badiali M, Cao A, Dokal I: A novel DKC1 mutation, severe combined immunodeficiency ( $\left.T^{+} B^{-} N K^{-} S C I D\right)$ and bone marrow transplantation in an infant with Hoyeraal-Hreidarsson syndrome. Br J Haematol 2002, 119:765-768.

18. Denianke KS, Frieden IJ, Cowan MJ, Williams ML, McCalmont TH: Cutaneous manifestations of maternal engraftment in patients with severe combined immunodeficiency: a clinicopathologic study. Bone Marrow Transplant 2001, 28:227-233.

19. Palmer K, Green TD, Roberts JL, Sajaroff E, Cooney M, Parrott R, Chen DF, Reinsmoen NL, Buckley RH: Unusual clinical and immunologic manifestations of transplacentally acquired maternal $\mathrm{T}$ cells in severe combined immunodeficiency. J Allergy Clin Immunol 2007, 120:423-428.

20. Kobrynski $L$, Abramowsky C: Monoclonal IgA gammopathy due to maternal $B$ cells in an infant with severe combined immunodeficiency (SCID) prior to hematopoietic stem cell transplantation. J Pediatr Hematol Oncol 2006, 28:53-56.

21. Tezcan I, Ersoy F, Sanal O, Turul T, Uckan D, Balci S, Hicsonmez G, Prieur M, Caillat-Zucmann S, Le Deist F, De Saint Basile G: Long-term survival in severe combined immune deficiency: the role of persistent maternal engraftment. J Pediatr 2005, 146:137-140.

22. Villa A, Santagata S, Bozzi F, Imberti L, Notarangelo LD: Omenn syndrome: a disorder of Rag1 and Rag2 genes. J Clin Immunol 1999, 19:87-97.

23. Villa A, Notarangelo LD, Roifman CM: Omenn syndrome: inflammation in leaky severe combined immunodeficiency. J Allergy Clin Immunol 2008, 122:1082-1086.

24. Roifman CM, Zhang J, Atkinson A, Grunebaum E, Mandel K: Adenosine deaminase deficiency can present with features of Omenn syndrome. J Allergy Clin Immunol 2008, 121:1056-1058.

25. Gruber TA, Shah AJ, Hernandez M, Crooks GM, Abdel-Azim H, Gupta S, McKnight S, White D, Kapoor N, Kohn DB: Clinical and genetic heterogeneity in Omenn syndrome and severe combined immune deficiency. Pediatr Transplant 2009, 13:244-250.

26. Giliani S, Bonfim C, de Saint Basile G, Lanzi G, Brousse N, Koliski A, Malvezzi M, Fischer A, Notarangelo LD, Le Deist F: Omenn syndrome in an infant with IL7RA gene mutation. J Pediatr 2006, 148:272-274.
27. Ege M, Ma Y, Manfras B, Kalwak K, Lu H, Lieber MR, Schwarz K, Pannicke U: Omenn syndrome due to ARTEMIS mutations. Blood 2005, 105:4179-4186.

28. Grunebaum E, Bates A, Roifman CM: Omenn syndrome is associated with mutations in DNA ligase IV. J Allergy Clin Immunol 2008, 122:1219-1220.

29. Pignata C, Fiore M, Guzzetta V, Castaldo A, Sebastio G, Porta F, Guarino A: Congenital Alopecia and nail dystrophy associated with severe functional T-cell immunodeficiency in two sibs. Am J Med Genet 1996 65:167-170.

30. Markert ML, Alexieff MJ, Li J, Sarzotti M, Ozaki DA, Devlin BH, Sempowski GD, Rhein ME, Szabolcs P, Hale LP, Buckley RH, Coyne KE, Rice HE, Mahaffey SM, Skinner MA: Complete DiGeorge syndrome: development of rash, lymphadenopathy, and oligoclonal T cells in 5 cases. J Allergy Clin Immunol 2004, 113:734-741.

31. Gennery AR, Slatter MA, Rice J, Hoefsloot LH, Barge D, McLean-Tooke A, Montgomery T, Goodship JA, Burt AD, Flood TJ, Abinun M, Cant AJ, Johnson D: Mutations in CHD7 in patients with CHARGE syndrome cause $\mathrm{TB}^{+}$natural killer cell ${ }^{+}$severe combined immune deficiency and may cause Omenn-like syndrome. Clin Exp Immunol 2008, 153:75-80.

32. Roifman CM, Gu Y, Cohen A: Mutations in the RNA component of RNase mitochondrial RNA processing might cause Omenn syndrome. I Allergy Clin Immunol 2006, 117:897-903.

33. Liston A, Enders A, Siggs OM: Unravelling the association of partial T-cell immunodeficiency and immune dysregulation. Nat Rev Immunol 2008, 8:545-558

34. Poliani PL, Facchetti F, Ravanini M, Gennery AR, Villa A, Roifman CM, Notarangelo LD: Early defects in human T-cell development severely affect distribution and maturation of thymic stromal cells: possible implications for the pathophysiology of Omenn syndrome. Blood 2009, 114:105-108.

35. Cassani B, Poliani PL, Moratto D, Sobacchi C, Marrella V, Imperatori L, Vairo D, Plebani A, Giliani S, Vezzoni P, Facchetti F, Porta F, Notarangelo LD, Villa A, Badolato R: Defect of regulatory T cells in patients with Omenn syndrome. J Allergy Clin Immunol 2010, 125:209-216.

36. Niehues T, Perez-Becker R, Schuetz C: More than just SCID - the phenotypic range of combined immunodeficiencies associated with mutations in the recombinase activating genes (RAG) 1 and 2. Clin Immunol 2010, 135:183-192.

37. Notarangelo LD, Roifman CM, Giliani S: Cartilage-hair hypoplasia: molecular basis and heterogeneity of the immunological phenotype. Curr Opin Allergy Clin Immunol 2008, 8:534-539.

38. Buckley RH: Variable phenotypic expression of mutations in genes of the immune system. J Clin Invest 2005, 115:2974-2976.

39. Umetsu DT, Schlossman CM, Ochs HD, Hershfield MS: Heterogeneity of phenotype in two siblings with adenosine deaminase deficiency. J Allergy Clin Immunol 1994, 93:543-550

40. Pasic S, Djuricic S, Ristic G, Slavkovic B: Recombinase-activating gene 1 immunodeficiency: different immunological phenotypes in three siblings. Acta Paediatr 2009, 98:1062-1064

41. Wada T, Candotti F: Somatic mosaicism in primary immune deficiencies. Curr Opin Allergy Clin Immunol 2008, 8:510-514.

42. Williamson AP, Montgomery JR, South MA, Wilson R, (Eds): A special report four-year study of a boy with combined immune deficiency maintained in strict reverse isolation from birth. Pediatr Res 1977, 11:63-89.

43. Paschall VL, Brown LA, Lawrence EC, Karol RA, Lotzova E, Brown BS, Shearer WT: Immunoregulation in an isolated 12-year-old boy with congenital severe combined immunodeficiency. Pediatr Res 1984, 18:723-728.

44. Shearer WT, Ritz J, Finegold MJ, Guerra IC, Rosenblatt HM, Lewis DE, Pollack MS, Taber LH, Sumaya CV, Grumet FC, Cleary ML, Warnke R, Sklar J: Epstein-Barr virus-associated B-cell proliferations of diverse clonal origins after bone marrow transplantation in a 12-year-old patient with severe combined immunodeficiency. N Engl J Med 1985, 312:1151-1159.

45. Noguchi M, Yi H, Rosenblatt HM, Filipovich AH, Adelstein S, Modi WS, McBride OW, Leonard WJ: Interleukin-2 receptor gamma chain mutation results in X-linked severe combined immunodeficiency in humans. Cell 1993, 73:147-157.

46. Berg LJ: The "bubble boy" paradox: an answer that led to a question. $J$ Immunol 2008, 181:5815-5816.

47. Rochman $Y$, Spolski R, Leonard WJ: New insights into the regulation of $T$ cells by $\gamma_{c}$ family cytokines. Nat Rev Immunol 2009, 9:480-490. 
48. Laffort C, Le Deist F, Favre M, Caillat-Zucman S, Radford-Weiss I, Debré M, Fraitag S, Blanche S, Cavazzana-Calvo M, de Saint Basile G, de Villartay JP, Giliani S, Orth G, Casanova JL, Bodemer C, Fischer A: Severe cutaneous papillomavirus disease after haemopoietic stem-cell transplantation in patients with severe combined immune deficiency caused by common Yc cytokine receptor subunit or JAK-3 deficiency. Lancet 2004, 363:2051-2054.

49. De Ravin SS, Malech HL: Partially corrected X-linked severe combined immunodeficiency: long-term problems and treatment options. Immunol Res 2009, 43:223-242.

50. Hacein-Bey-Abina S, Hauer J, Lim A, Picard C, Wang GP, Berry CC, Martinache C, Rieux-Laucat F, Latour S, Belohradsky BH, Leiva L, Sorensen R, Debré M, Casanova JL, Blanche S, Durandy A, Bushman FD, Fischer A, Cavazzana-Calvo M: Efficacy of gene therapy for X-linked severe combined immunodeficiency. N Engl J Med 2010, 363:355-364.

51. Pesu M, Candotti F, Husa M, Hofmann SR, Notarangelo LD, O'Shea JJ: Jak3, severe combined immunodeficiency, and a new class of immunosuppressive drugs. Immunol Rev 2005, 203:127-142.

52. Ghoreschi K, Laurence A, O'Shea JJ: Janus kinases in immune cell signaling. Immunol Rev 2009, 228:273-287.

53. Puel A, Leonard WJ: Mutations in the gene for the IL-7 receptor result in $\mathrm{T}^{-}{ }^{+} \mathrm{NK}^{+}$severe combined immunodeficiency disease. Curr Opin Immunol 2000, 12:468-473.

54. Giliani S, Mori L, de Saint Basile G, Le Deist F, Rodriguez-Perez C, Forino C, Mazzolari E, Dupuis S, Elhasid R, Kessel A, Galambrun C, Gil J, Fischer A, Etzioni A, Notarangelo LD: Interleukin-7 receptor a (IL-7Ra) deficiency: cellular and molecular bases. Analysis of clinical, immunological, and molecular features in 16 novel patients. Immunol Rev 2005, 203:110-126.

55. Takada K, Jameson SC: Naive T cell homeostasis: from awareness of space to a sense of place. Nat Rev Immunol 2010, 9(12):823-832.

56. McGhee SA, Stiehm ER, Cowan M, Krogstad P, McCabe ER: Two-tiered universal newborn screening strategy for severe combined immunodeficiency. Mol Genet Metab 2005, 86:427-430.

57. Nemazee D: Receptor editing in lymphocyte development and central tolerance. Nat Rev Immunol 2006, 6:728-740.

58. Smith-Garvin JE, Koretzky GA, Jordan MS: T cell activation. Annu Rev Immunol 2009, 27:591-619.

59. Conley ME, Dobbs AK, Farmer DM, Kilic S, Paris K, Grigoriadou S, CoustanSmith E, Howard V, Campana D: Primary B cell immunodeficiencies: comparisons and contrasts. Annu Rev Immunol 2009, 27:199-227.

60. de Villartay JP: V(D)J recombination deficiencies. Adv Exp Med Biol 2009, 650:46-58.

61. Ochi T, Sibanda BL, Wu Q, Chirgadze DY, Bolanos-Garcia VM, Blundell TL: Structural biology of DNA repair: spatial organisation of the multicomponent complexes of nonhomologous end joining. J Nucleic Acids 2010, 2010:pii: 621695.

62. Dvorak CC, Cowan MJ: Radiosensitive severe combined immunodeficiency disease. Immunol Allergy Clin North Am 2010, 30:125-142.

63. Sobacchi $C$, Marrella $V$, Rucci F, Vezzoni P, Villa A: RAG-dependent primary immunodeficiencies. Hum Mutat 2006, 27:1174-1184

64. Li L, Moshous D, Zhou Y, Wang J, Xie G, Salido E, Hu D, de Villartay JP, Cowan MJ: A founder mutation in Artemis, an SNM1-like protein, causes SCID in Athabascan-speaking Native Americans. J Immunol 2002, 168:6323-6329.

65. Chistiakov DA, Voronova NV, Chistiakov AP: Ligase IV syndrome. Eur J Med Genet 2009, 52:373-378.

66. Buck D, Malivert $L$, de Chasseval $R$, Barraud A, Fondanèche MC, Sanal O, Plebani A, Stéphan JL, Hufnagel M, le Deist F, Fischer A, Durandy A, de Villartay JP, Revy P: Cernunnos, a novel nonhomologous end-joining factor, is mutated in human immunodeficiency with microcephaly. Cell 2006, 124:287-299.

67. van der Burg M, van Dongen JJ, van Gent DC: DNA-PKcs deficiency in human: long predicted, finally found. Curr Opin Allergy Clin Immunol 2009, 9:503-509.

68. Recio MJ, Moreno-Pelayo MA, Kiliç SS, Guardo AC, Sanal O, Allende LM, Pérez-Flores V, Mencía A, Modamio-Høybjør S, Seoane E, Regueiro JR: Differential biological role of CD3 chains revealed by human immunodeficiencies. J Immunol 2007, 178:2556-2564.

69. Roberts JL, Lauritsen JP, Cooney M, Parrott RE, Sajaroff EO, Win CM, Keller MD, Carpenter JH, Carabana J, Krangel MS, Sarzotti M, Zhong XP,
Wiest DL, Buckley $\mathrm{RH}: \mathrm{T}^{-} \mathrm{B}^{+} \mathrm{NK}^{+}$severe combined immunodeficiency caused by complete deficiency of the $\mathrm{CD} 3 \zeta$ subunit of the T-cell antigen receptor complex. Blood 2007, 109:3198-3206.

70. Tchilian EZ, Wallace DL, Wells RS, Flower DR, Morgan G, Beverley PC: A deletion in the gene encoding the CD45 antigen in a patient with SCID. $\mathrm{J}$ Immunol 2001, 166:1308-1313.

71. Tchilian EZ, Beverley PC: Altered CD45 expression and disease. Trends Immunol 2006, 27:146-153.

72. Au-Yeung BB, Deindl S, Hsu LY, Palacios EH, Levin SE, Kuriyan J, Weiss A The structure, regulation, and function of ZAP-70. Immunol Rev 2009, 228:41-57.

73. Goldman FD, Ballas ZK, Schutte BC, Kemp J, Hollenback C, Noraz N Taylor N: Defective expression of p56lck in an infant with severe combined immunodeficiency. J Clin Invest 1998, 102:421-429.

74. Hubert $P$, Bergeron F, Ferreira V, Seligmann M, Oksenhendler E, Debre $P$, Autran B: Defective p56Lck activity in T cells from an adult patient with idiopathic CD4+ lymphocytopenia. Int Immunol 2000, 12:449-457.

75. Lagresle-Peyrou C, Six EM, Picard C, Rieux-Laucat F, Michel V, Ditadi A Demerens-de Chappedelaine C, Morillon E, Valensi F, Simon-Stoos KL, Mullikin JC, Noroski LM, Besse C, Wulffraat NM, Ferster A, Abecasis MM, Calvo F, Petit C, Candotti F, Abel L, Fischer A, Cavazzana-Calvo M: Human adenylate kinase 2 deficiency causes a profound hematopoietic defect associated with sensorineural deafness. Nat Genet 2009, 41:106-111.

76. Pannicke U, Hönig M, Hess I, Friesen C, Holzmann K, Rump EM, Barth TF, Rojewski MT, Schulz A, Boehm T, Friedrich W, Schwarz K: Reticular dysgenesis (aleukocytosis) is caused by mutations in the gene encoding mitochondrial adenylate kinase 2. Nat Genet 2009, 41:101-105.

77. Dzeja P, Terzic A: Adenylate kinase and AMP signaling networks: Metabolic monitoring, signal communication and body energy sensing. Int J Mol Sci 2009, 10:1729-1772.

78. Klein C, Grudzien M, Appaswamy G, Germeshausen M, Sandrock I, Schäffer AA, Rathinam C, Boztug K, Schwinzer B, Rezaei N, Bohn G, Melin M, Carlsson G, Fadeel B, Dahl N, Palmblad J, Henter Jl, Zeidler C, Grimbacher B, Welte K: HAX1 deficiency causes autosomal recessive severe congenital neutropenia (Kostmann disease). Nat Genet 2007, 39:86-92.

79. Cassani B, Mirolo M, Cattaneo F, Benninghoff U, Hershfield M, Carlucci F, Tabucchi A, Bordignon C, Roncarolo MG, Aiuti A: Altered intracellular and extracellular signaling leads to impaired T-cell functions in ADA-SCID patients. Blood 2008, 111:4209-4219.

80. Sauer AV, Aiuti A: New insights into the pathogenesis of adenosine deaminase-severe combined immunodeficiency and progress in gene therapy. Curr Opin Allergy Clin Immunol 2009, 9:496-502.

81. Sauer AV, Mrak E, Hernandez RJ, Zacchi E, Cavani F, Casiraghi M, Grunebaum E, Roifman CM, Cervi MC, Ambrosi A, Carlucci F, Roncarolo MG, Villa A, Rubinacci A, Aiuti A: ADA-deficient SCID is associated with a specific microenvironment and bone phenotype characterized by RANKL/OPG imbalance and osteoblast insufficiency. Blood 2009, 114:3216-3226

82. Hönig M, Albert MH, Schulz A, Sparber-Sauer M, Schütz C, Belohradsky B, Güngör T, Rojewski MT, Bode H, Pannicke U, Lippold D, Schwarz K, Debatin KM, Hershfield MS, Friedrich W: Patients with adenosine deaminase deficiency surviving after hematopoietic stem cell transplantation are at high risk of CNS complications. Blood 2007 109:3595-3602.

83. Barić I: Inherited disorders in the conversion of methionine to homocysteine. J Inherit Metab Dis 2009, 32:459-471.

84. Gaspar HB, Aiuti A, Porta F, Candotti F, Hershfield MS, Notarangelo LD: How I treat ADA deficiency. Blood 2009, 114:3524-3532.

85. Gaspar HB: Bone marrow transplantation and alternatives for adenosine deaminase deficiency. Immunol Allergy Clin North Am 2010, 30:221-236.

86. Aiuti A, Cattaneo F, Galimberti S, Benninghoff U, Cassani B, Callegaro L, Scaramuzza S, Andolfi G, Mirolo M, Brigida I, Tabucchi A, Carlucci F, Eibl M, Aker M, Slavin S, Al-Mousa H, Al Ghonaium A, Ferster A, Duppenthaler A, Notarangelo L, Wintergerst U, Buckley RH, Bregni M, Marktel S, Valsecchi MG, Rossi P, Ciceri F, Miniero R, Bordignon C, Roncarolo MG: Gene therapy for immunodeficiency due to adenosine deaminase deficiency. N Engl J Med 2009, 360:447-458.

87. Aytekin C, Dogu F, Tanir G, Guloglu D, Santisteban I, Hershfield MS, Ikinciogullari A: Purine nucleoside phosphorylase deficiency with fatal course in two sisters. Eur J Pediatr 2010, 169:311-314. 
88. Rodewald HR: Thymus organogenesis. Annu Rev Immunol 2008, 26:355-388.

89. Poliani PL, Vermi W, Facchetti F: Thymus microenvironment in human primary immunodeficiency diseases. Curr Opin Allergy Clin Immunol 2009, 9:489-95.

90. Frank J, Pignata C, Panteleyev AA, Prowse DM, Baden $H$, Weiner $L$, Gaetaniello L, Ahmad W, Pozzi N, Cserhalmi-Friedman PB, Aita VM Uyttendaele H, Gordon D, Ott J, Brissette JL, Christiano AM: Exposing the human nude phenotype. Nature 1999, 398:473-474.

91. Adriani M, Martinez-Mir A, Fusco F, Busiello R, Frank J, Telese S, Matrecano E, Ursini MV, Christiano AM, Pignata C: Ancestral founder mutation of the nude (FOXN1) gene in congenital severe combined immunodeficiency associated with alopecia in southern Italy population. Ann Hum Genet 2004, 68:(Pt 3):265-268.

92. Amorosi S, D'Armiento M, Calcagno G, Russo I, Adriani M, Christiano AM, Weiner L, Brissette $J$, Pignata C: FOXN1 homozygous mutation associated with anencephaly and severe neural tube defect in human athymic Nude/SCID fetus. Clin Genet 2008, 73:380-384.

93. Markert ML, Devlin BH, Chinn IK, McCarthy EA: Thymus transplantation in complete DiGeorge anomaly. Immunol Res 2009, 44:61-70.

94. Kobrynski LJ, Sullivan KE: Velocardiofacial syndrome, DiGeorge syndrome: the chromosome 22q11.2 deletion syndromes. Lancet 2007 370:1443-1452.

95. Blake KD, Prasad C: CHARGE syndrome. Orphanet J Rare Dis 2006, 1:34.

96. Jyonouchi S, McDonald-McGinn DM, Bale S, Zackai EH, Sullivan KE: CHARGE (coloboma, heart defect, atresia choanae, retarded growth and development, genital hypoplasia, ear anomalies/deafness) syndrome and chromosome 22q11.2 deletion syndrome: a comparison of immunologic and nonimmunologic phenotypic features. Pediatrics 2009, 123:e871-877.

97. Allen VM, Armson BA, Wilson RD, Allen VM, Blight C, Gagnon A, Johnson JA, Langlois S, Summers A, Wyatt P, Farine D, Armson BA, Crane J, Delisle MF, Keenan-Lindsay L, Morin V, Schneider CE, Van Aerde J, Society of Obstetricians and Gynecologists of Canada: Teratogenicity associated with pre-existing and gestational diabetes. J Obstet Gynaecol Can 2007, 29:927-944.

98. Rice HE, Skinner MA, Mahaffey SM, Oldham KT, Ing RJ, Hale LP, Markert ML: Thymic transplantation for complete DiGeorge syndrome: medical and surgical considerations. J Pediatr Surg 2004, 39:1607-1615.

99. Markert ML, Devlin BH, McCarthy EA: Thymus transplantation. Clin Immunol 2010, 135:236-246

100. McGhee SA, Lloret MG, Stiehm ER: Immunologic reconstitution in 22q deletion (DiGeorge) syndrome. Immunol Res 2009, 45:37-45.

101. Feske S: Calcium signalling in lymphocyte activation and disease. Nat Rev Immunol $2007,7 \cdot 690-702$

102. Shiow LR, Roadcap DW, Paris K, Watson SR, Grigorova IL, Lebet T, An J, Xu Y, Jenne CN, Föger N, Sorensen RU, Goodnow CC, Bear JE, Puck JM, Cyster JG: The actin regulator coronin $1 \mathrm{~A}$ is mutant in a thymic egressdeficient mouse strain and in a patient with severe combined immunodeficiency. Nat Immunol 2008, 9:1307-1315.

103. Shiow LR, Paris K, Akana MC, Cyster JG, Sorensen RU, Puck JM: Severe combined immunodeficiency (SCID) and attention deficit hyperactivity disorder (ADHD) associated with a Coronin-1A mutation and a chromosome 16p11.2 deletion. Clin Immunol 2009, 131:24-30.

104. Burkhardt JK, Carrizosa E, Shaffer MH: The actin cytoskeleton in T cell activation. Annu Rev Immunol 2008, 26:233-259.

105. Picard C, Fischer A: Hematopoietic stem cell transplantation and other management strategies for MHC class II deficiency. Immunol Allergy Clin North Am 2010, 30:173-178.

106. Walne AJ, Dokal I: Advances in the understanding of dyskeratosis congenita. Br J Haematol 2009, 145:164-172.

107. Marrone A, Walne A, Tamary H, Masunari Y, Kirwan M, Beswick R, Vulliamy T, Dokal I: Telomerase reverse-transcriptase homozygous mutations in autosomal recessive dyskeratosis congenita and Hoyeraal-Hreidarsson syndrome. Blood 2007, 110:4198-4205.

108. O'Sullivan RJ, Karlseder J: Telomeres: protecting chromosomes against genome instability. Nat Rev Mol Cell Biol 2010, 11:171-181.

109. Walne AJ, Vulliamy T, Beswick R, Kirwan M, Dokal I: TINF2 mutations result in very short telomeres: analysis of a large cohort of patients with dyskeratosis congenita and related bone marrow failure syndromes. Blood 2008, 112:3594-3600.
110. Touzot F, Callebaut I, Soulier J, Gaillard L, Azerrad C, Durandy A, Fischer A, de Villartay JP, Revy P: Function of Apollo (SNM1B) at telomere highlighted by a splice variant identified in a patient with HoyeraalHreidarsson syndrome. Proc Natl Acad Sci USA 2010, 107:10097-10102.

111. Revy P, Busslinger M, Tashiro K, Arenzana F, Pillet P, Fischer A, Durandy A: A syndrome involving intrauterine growth retardation, microcephaly, cerebellar hypoplasia, B lymphocyte deficiency, and progressive pancytopenia. Pediatrics 2000, 105:E39.

112. Borzutzky A, Crompton B, Bergmann AK, Giliani S, Baxi S, Martin M, Neufeld EJ, Notarangelo LD: Reversible severe combined immunodeficiency phenotype secondary to a mutation of the protoncoupled folate transporter. Clin Immunol 2009, 133:287-294.

113. Mazzolari E, de Martiis D, Forino C, Lanfranchi A, Giliani S, Marzollo R, Airò P, Imberti L, Porta F, Notarangelo LD: Single-center analysis of long-term outcome after hematopoietic cell transplantation in children with congenital severe T cell immunodeficiency. Immunol Res 2009, 44:4-17.

114. Neven B, Leroy S, Decaluwe H, Le Deist F, Picard C, Moshous D, Mahlaoui N, Debré M, Casanova JL, Dal Cortivo L, Madec Y, Hacein-BeyAbina S, de Saint Basile G, de Villartay JP, Blanche S, Cavazzana-Calvo M, Fischer A: Long-term outcome after hematopoietic stem cell transplantation of a single-center cohort of 90 patients with severe combined immunodeficiency. Blood 2009, 113:4114-4124.

115. Railey MD, Lokhnygina Y, Buckley RH: Long-term clinical outcome of patients with severe combined immunodeficiency who received related donor bone marrow transplants without pretransplant chemotherapy or post-transplant GVHD prophylaxis. J Pediatr 2009, 155:834-840

116. Gennery AR, Slatter MA, Grandin L, Taupin P, Cant AJ, Veys P, Amrolia PJ, Gaspar HB, Davies EG, Friedrich W, Hoenig M, Notarangelo LD, Mazzolari E, Porta F, Bredius RG, Lankester AC, Wulffraat NM, Seger R, Güngör T, Fasth A, Sedlacek P, Neven B, Blanche S, Fischer A, Cavazzana-Calvo M, Landais P, Inborn Errors Working Party of the European Group for Blood and Marrow Transplantation; European Society for Immunodeficiency: Transplantation of hematopoietic stem cells and long-term survival for primary immunodeficiencies in Europe: entering a new century, do we do better? J Allergy Clin Immunol 2010, 126:602-610.

117. Cuvelier GD, Schultz KR, Davis J, Hirschfeld AF, Junker AK, Tan R, Turvey SE: Optimizing outcomes of hematopoietic stem cell transplantation for severe combined immunodeficiency. Clin Immunol 2009, 131:179-188.

118. Veys P: Reduced intensity transplantation for primary immunodeficiency disorders. Immunol Allergy Clin North Am 2010, 30:103-124.

119. Qasim W, Gaspar HB, Thrasher AJ: Progress and prospects: gene therapy for inherited immunodeficiencies. Gene Ther 2009, 16:1285-1291.

120. Fischer A, Hacein-Bey-Abina S, Cavazzana-Calvo M: 20 years of gene therapy for SCID. Nat Immunol 2010, 11:457-460.

121. Kohn DB, Sadelain M, Glorioso JC: Occurrence of leukaemia following gene therapy of X-linked SCID. Nat Rev Cancer 2003, 3:477-488.

122. Howe SJ, Mansour MR, Schwarzwaelder K, Bartholomae C, Hubank M, Kempski H, Brugman MH, Pike-Overzet K, Chatters SJ, de Ridder D, Gilmour KC, Adams S, Thornhill SI, Parsley KL, Staal FJ, Gale RE, Linch DC, Bayford J, Brown L, Quaye M, Kinnon C, Ancliff P, Webb DK, Schmidt M, von Kalle C, Gaspar HB, Thrasher AJ: Insertional mutagenesis combined with acquired somatic mutations causes leukemogenesis following gene therapy of SCID-X1 patients. J Clin Invest 2008, 118:3143-3150.

123. Zhou S, Mody D, DeRavin SS, Hauer J, Lu T, Ma Z, Hacein-Bey Abina S, Gray JT, Greene MR, Cavazzana-Calvo M, Malech HL, Sorrentino BP: A selfinactivating lentiviral vector for SCID-X1 gene therapy that does not activate LMO2 expression in human T cells. Blood 2010, 116:900-908.

124. Cavazzana-Calvo M, Payen E, Negre O, Wang G, Hehir K, Fusil F, Down J, Denaro M, Brady T, Westerman K, Cavallesco R, Gillet-Legrand B, Caccavelli L, Sgarra R, Maouche-Chrétien L, Bernaudin F, Girot R, Dorazio R, Mulder GJ, Polack A, Bank A, Soulier J, Larghero J, Kabbara N, Dalle B, Gourmel B, Socie G, Chrétien S, Cartier N, Aubourg P, Fischer A, Cornetta K, Galacteros F, Beuzard Y, Gluckman E, Bushman F, Hacein-Bey-Abina S, Leboulch P: Transfusion independence and HMGA2 activation after gene therapy of human $\beta$-thalassaemia. Nature 2010, 467:318-322.

doi:10.1186/1824-7288-36-76

Cite this article as: Cossu: Genetics of SCID. Italian Journal of Pediatrics $201036: 76$ 